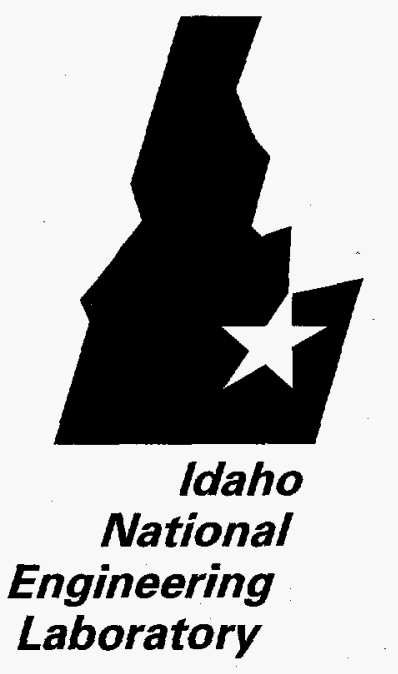

INEL/EXT-97-0057

January 1997

\title{
Comprehensive Characterization Report on Winter Quarters Bay, McMurdo Station, Antarctica
}
A. B. Crockett
G. J. White

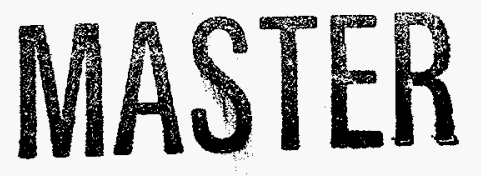

L O C K HEED MA RTIN/

OTIBUTION OF THIS DOCUMENT IS UNLMMT 


\title{
Comprehensive Characterization Report on Winter Quarters Bay, McMurdo Station, Antarctica
}

\author{
A. B. Crockett \\ G. J. White
}

Published January 1997

Idaho National Engineering and Environmental Laboratory

Environmental Assessment Technologies

Lockheed Martin Idaho Technologies Company

Idaho Falls, Idaho 83415

Prepared for the National Science Foundation

Office of Polar Programs

Under Interagency Agreement No. DPP-91102787

with U.S. Department of Energy

under DOE Idaho Operations Office

Contract DE-AC07-94ID13223 


\section{DISCLAMIER}

Portions of this document may be illegible in electronic image produets. Images are produced from the best available original document. 


\section{ABSTRACT}

Winter Quarters Bay is a small embayment located adjacent to the United States' largest base in Antarctica, McMurdo Station. The bay itself is about $250 \mathrm{~m}$ wide and equally long, with a maximum water depth of $33 \mathrm{~m}$. It is so named because many early Antarctic explorers wintered at the site. McMurdo Station, which is managed by the National Science Foundation's Office of Polar Programs, was constructed in 1955, has been in constant use since that time, and has a population of about 1,000 persons during the summer and about 250 people for the winter. The bay offers shelter for ships and an ice dock is used during January and February to offload fuel and cargo.

During earlier times, trash from the McMurdo Station was piled on the steep shoreline of the bay, doused with several thousand gallons of fuel and ignited. That practice has ceased and the site has been regraded to cover the waste. The bottom of the bay is littered with drums, equipment, tanks, tires, all sorts of metal objects, cables, etc., especially the southeastern side where dumping took place. The sediments are gravel in some places yet fine and fluid at other sites with coarse particles intermixed. The original benthic community is not well recorded but significant ecological changes have occurred. Sediments are contaminated with PCBs, metals, and hydrocarbon fuels.

This report summarizes available information on Winter Quarters Bay and was originally intended to be used by workshop participants to become familiar with the bay prior to becoming updated with unpublished data by various Antarctic investigators. The proposed workshop was to assist the National Science Foundation in determining whether and how the bay should be remediated and to develop an integrated research plan if additional data were needed. However, plans changed, the workshop was never conducted, but the briefing report was prepared. Most of this report reviews and summarizes other published data. The only new data are those from the Idaho National Engineering and Environmental Laboratory's investigation into the distribution of organic contaminants in the bay and sediment toxicity testing.

Key Words: Antarctica, Winter Quarters Bay, McMurdo Station, sediments, human impact, contamination 


\section{ACKNOWLEDGMENT}

This project was funded by the National Science Foundation, Office of Polar Programs, through Interagency Agreement No. DPP-9102787 with the U.S. Department of Energy. The authors wish to thank Antarctic Support Associates personnel for assisting in sample collection, on-site analysis of samples, and logistical support; William Engelmann, the U.S. Environmental Protection Agency and Neil Amick, Lockheed Environmental Systems and Technologies Company, who provided "oil-equivalent" screening data; and Huyen Huynh, Microbics Corporation, and Thomas Johnson, the U.S. Geological Survey, Midwest Science Center, for determining the toxicity of Winter Quarters Bay sediments using Microtox. 


\section{CONTENTS}

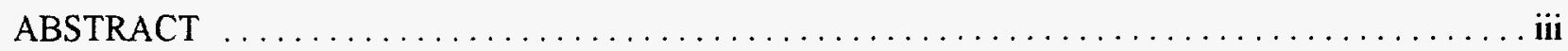

ACKNOWLEDGMENT $\ldots \ldots \ldots \ldots \ldots \ldots \ldots \ldots \ldots \ldots \ldots \ldots \ldots \ldots \ldots \ldots \ldots \ldots$

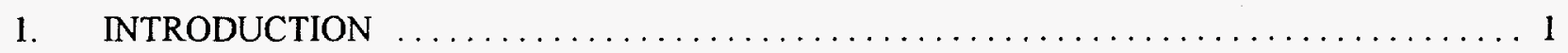

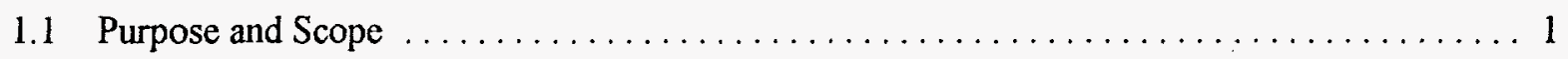

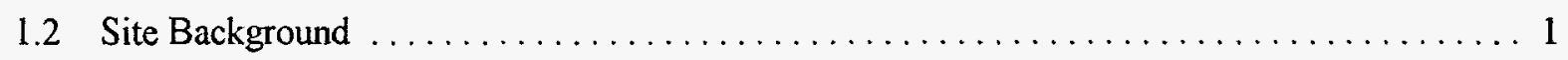

2. PHYSICAL CHARACTERISTICS OF WINTER QUARTERS BAY $\ldots \ldots \ldots \ldots \ldots \ldots \ldots \ldots 3$

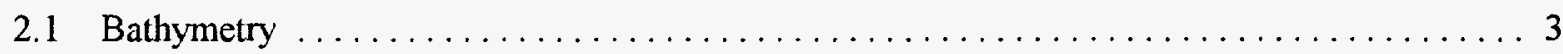

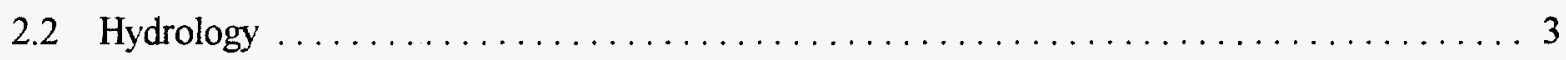

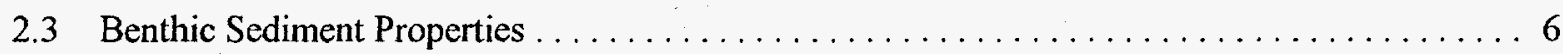

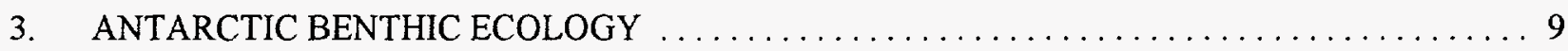

3.1 Benthic Communities of Nonimpacted McMurdo Sound $\ldots \ldots \ldots \ldots \ldots \ldots \ldots$

3.2 Natural Disturbance to Antarctic Benthic Communities $\ldots \ldots \ldots \ldots \ldots \ldots \ldots \ldots$

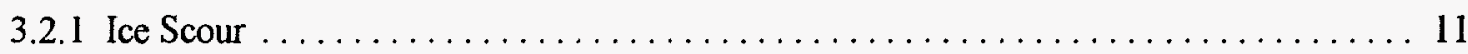

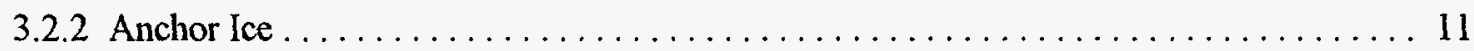

3.3 Vertical Zonation of Antarctic Benthic Communities $\ldots \ldots \ldots \ldots \ldots \ldots \ldots \ldots \ldots$

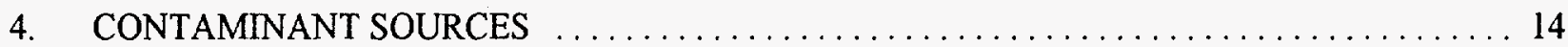

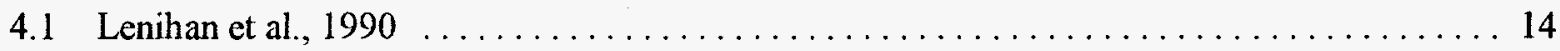

4.2 Risebrough, De Lappe, and Younghans-Haug, $1990 \ldots \ldots \ldots \ldots \ldots \ldots \ldots \ldots$

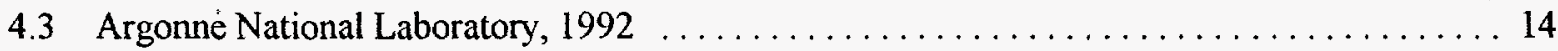

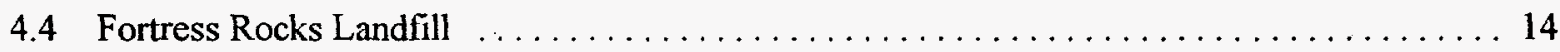

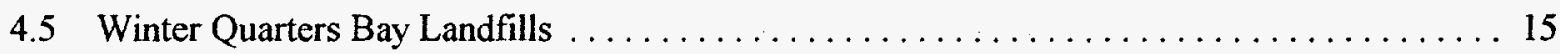

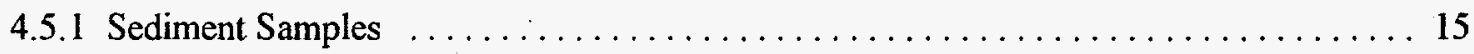


5. BENTHIC ECOLOGY AND ECOLOGICAL STRESS IN WINTERS QUARTERS BAY . . . . 18

5.1 Historical Information on Winter Quarters Bay Benthic Communities . . . . . . . . 19

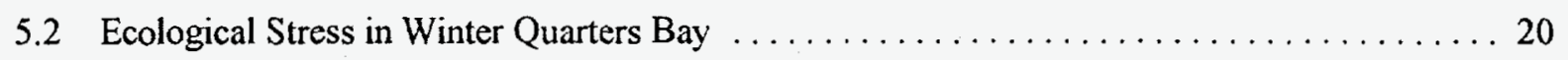

5.3 Comparison with Natural Disturbance $\ldots \ldots \ldots \ldots \ldots \ldots \ldots \ldots \ldots \ldots \ldots \ldots \ldots \ldots \ldots$

5.4 Recovery of Winter Quarters Bay Benthic Communities $\ldots \ldots \ldots \ldots \ldots \ldots \ldots \ldots$

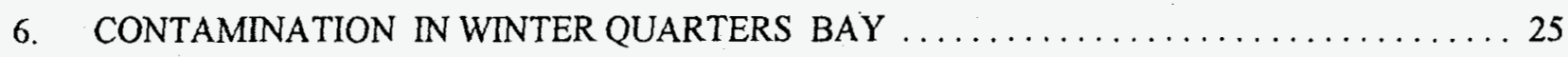

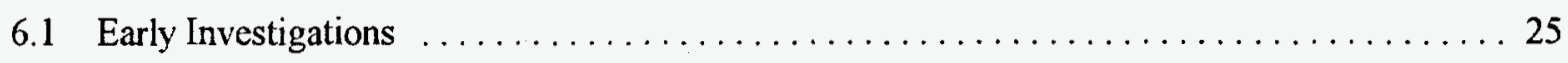

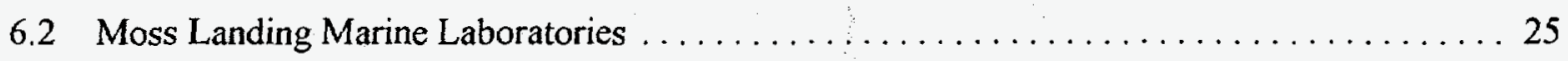

6.3 Idaho National Engineering and Environmental Laboratory Data $\ldots \ldots \ldots \ldots \ldots \ldots$

7. SUMMARY AND RECOMMENDATIONS $\ldots \ldots \ldots \ldots \ldots \ldots \ldots \ldots \ldots \ldots \ldots \ldots \ldots \ldots$

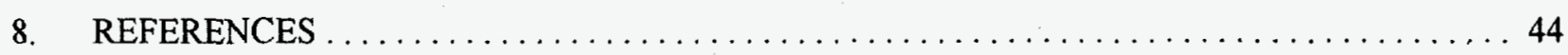

9. APPENDIX A - Coordinates and depths of Winter Quarters Bay sampling sites

\section{FIGURES}

1. Station locations and depths for Winter Quarters Bay, Antarctica $\ldots \ldots \ldots \ldots \ldots \ldots \ldots \ldots$

2. Mean spring/summer currents near McMurdo Station, Antarctica $\ldots \ldots \ldots \ldots \ldots \ldots \ldots \ldots$

3. Percent silt and clay in Winter Quarters Bay sediments, McMurdo Sound, Antarctica ........ 7

4. Total organic carbon in Winter Quarter Bay sediments, McMurdo Sound, Antarctica ....... 8

5. Sampling locations around McMurdo Station, Antarctica $\ldots \ldots \ldots \ldots \ldots \ldots \ldots \ldots \ldots$

6. Routine benthic monitoring station locations, McMurdo Station, Antarctica . . . . . . . . . 29

7. Total PCBs in Winter Quarters Bay sediments, McMurdo Sound, Antarctica . . . . . . ... 34

8. Total PAHs and oil-eq. in Winter Quarters Bay sediments, McMurdo Sound, Antarctica ...... 35 
9. Toxicity of Winter Quarters Bay sediments, McMurdo Sound, Antarctica

\section{TABLES}

1. Number of recorded benthic species for certain groups in Arctic and Antarctic regions

2. Summary of analytical data on sediments collected by Moss Landing Marine personnel, Winter Quarters Bay, McMurdo Sound, Antarctica, and reference sites

3. Summary of metals ( $\mathrm{ppm}$ ) and organic compounds ( $\mathrm{ppb}$ ) in biota samples from Winter Quarters Bay and reference sites

4. Summary of selected PAHs (ng/g) in Winter Quarters Bay sediments

5. Summary of INEEL analytical data on Winter Quarter Bay sediments 36

6. PCBs and PAHs in Winter Quarters Bay sediments 37

7. PCBs and PAHs in Winter Quarters Bay sediments normalized to $1 \%$ organic carbon 38 


\section{Comprehensive Characterization Report on Winter Quarters Bay, McMurdo Station, Antarctica}

\section{INTRODUCTION}

Winter Quarters Bay (WQB) is a small embayment located adjacent to the United States' largest base in Antarctica, McMurdo Station. The bay itself is about $250 \mathrm{~m}$ wide and equally long, with a maximum water depth of $33 \mathrm{~m}$. It is so named because many early Antarctic explorers wintered at the site. McMurdo Station is managed by the National Science Foundation (NSF), Office of Polar Programs. The station was constructed in 1955 and has been in constant use since that time. McMurdo Station has a population of about 1,000 persons during the summer and about 250 people for the winter. The bay offers shelter for ships, and an ice dock is used during January and February to offload fuel and cargo.

During earlier times, trash from McMurdo Station was piled on the steep shoreline of the bay, doused with several thousand gallons of fuel and ignited. That practice ceased in 1980, and the site has been regraded to cover the waste. The bottom is littered with debris such as drums, equipment, tanks, tires, all types of metal objects, and cables, especially on the southeastern side where dumping took place. The sediments are gravel in some places yet fine and fluid at other sites with coarse particles intermixed. The original benthic community is not well recorded but significant ecological changes appear to have occurred. Sediments are contaminated with polychlorinated biphenyls (PCBs), metals, and hydrocarbon fuels.

\subsection{Purpose and Scope}

This report summarizes available information on Winter Quarters Bay and was originally intended to be used by workshop participants to become familiar with the bay. Participants at the workshop would then have been updated by Antarctic researchers on the results of their unpublished results. The proposed workshop was intended to assist the NSF in determining whether and how to remediate the bay, and to develop an integrated research plan if additional data were needed. This workshop was never conducted, though the briefing report was prepared. Most of the report reviews and summarizes other published data. The new data are those from the Idaho National Engineering and Environmental Laboratory (INEEL) investigation into the distribution of organic contaminants in the bay and sediment toxicity testing.

\subsection{Site Background}

McMurdo Station ( 77 degrees 51 minutes south latitude and 166 degrees 40 minutes east longitude) is the major support station for the U.S. Antarctic Program. The U.S. Navy began constructing McMurdo Station during the 1955-56 season to be used as a logistical support base. By the mid-1960s, the Navy began to construct permanent buildings. The station is located on Ross Island, and currently consists of more than 100 structures, extensive storage yards, an ice pier, an annual sea ice runway, a skiway, a helicopter landing area, and other ancillary structures and features. During the $1989-90$ austral summer season, the average monthly population at McMurdo Station and Williams Field was 1,130 people (NSFA 1990), though efforts are being made to restrict this number somewhat. The highest average monthly population during the 
1989-90 year was 1,257 persons in November with a maximum population at any given time of 1,350 . During the austral winter, the population at McMurdo has ranged from 100 to 250 persons, depending on the amount of scientific research, construction, and renovation scheduled.

During the 1989-90 and 1990-91 austral summer seasons, improvements to the wastewater outfall were begun (NSF 1989). The outfall was relocated so that it would eventually discharge about $15 \mathrm{~m}$ below the surface at a new jetty designed to protect it. Storm damage prevented completion of the outfall until December 1991 (Crockett 1994). A macerator to grind solids in the wastewater was installed during the 1990 season. Monitoring of the outfall discharge has been performed since 1989 to determine the need for additional modifications to reduce impacts on the marine ecosystem.

During the 1980-81 season, a solid waste management area was built at Fortress Rocks to replace the dump site along the shore of the bay (NSFA 1981). A partial cleanup of the old dump site at Winter Quarters Bay was completed and the area was covered with fill and graded.

The ice pier at Winter Quarter Bay is used to dock vessels for unloading cargo and petroleum products and for loading waste and other materials to be retrograded. The pier is constructed during the winter by laying a matrix of steel cable over the ice surface and flooding it repeatedly with water. Immediately before use, approximately $15 \mathrm{~cm}$ of locally collected earth material is spread over the top of the pier to provide a working surface and insulation against solar heating. This material is scraped off at the end of each year for reuse. Periodically, the ice pier deteriorates and must be separated from the shoreline, towed out to sea and replaced.

Resupply operations by sea begin in early January with the arrival of a U.S. Coast Guard icebreaker to open a channel for the two resupply ships and to provide transportation and support for science parties and other operations. A tanker vessel arrives at McMurdo in late January and refuels McMurdo Station and the Coast Guard icebreaker. During the 1988-89 season, the tanker unloaded 7.9 million L of JP-4 and 13.2 million L of diesel fuel arctic. During the 1989-90 season, the tanker unloaded 25.2 million L of JP-8 and $570,000 \mathrm{~L}$ of unleaded gasoline. The tanker also provided diesel fuel marine directly to the Coast Guard icebreaker, as needed. In 1990, the U.S. Antarctic Program implemented a single fuel policy that involved replacing diesel fuel arctic and JP-4 with JP-8 wherever possible. On the return trip to the United States, the tanker transports bulk quantities of waste petroleum generated at U.S. Antarctic Program facilities.

A cargo vessel arrives at McMurdo in early February, shortly after the tanker leaves, and unloads cargo for approximately 10 to 12 days. On its return voyage, the cargo vessel transports materials and waste from McMurdo and Scott Base to the United States and New Zealand. Occasionally, the cargo ship may make a second trip to New Zealand to transport excess cargo that the ship was unable to carry on its first trip. From 1989-90, the vessel unloaded about 5,900 metric tons of cargo at McMurdo, and loaded 2,170 metric tons of retrograde materials for transport back to New Zealand and Port Hueneme. 


\section{PHYSICAL CHARACTERISTICS OF WINTER QUARTERS BAY}

\subsection{Bathymetry}

Near the mouth of Winter Quarters Bay is a relatively shallow submarine ridge. Water depths along this ridge are as shallow as $13 \mathrm{~m}$ near the center of the mouth of the bay. However, water depths are considerably greater within the main portion of the bay, which has a mean depth is approximately $20 \mathrm{~m}$ and a maximum depth of at least $33 \mathrm{~m}$.(Figure 1). The deepest region of the bay is located in the center of the bay, well away from the mouth of the bay.

The presence of this ridge in combination with the Hut Point Peninsula tend to isolate the bay from the rest of McMurdo Sound. This isolation has potential ramifications. For example, the ridge tends to prevent entry of icebergs into the bay, in effect protecting the benthic communities from physical damage caused by floating ice. The ridge also likely reduces currents within the bay (Figure 2), though current data from within the bay is lacking. The B and C current meters near the mouth of Winter Quarters Bay, as depicted in Figure 2, showed a net transport of less than $1 \mathrm{~cm} /$ second.

The physical structure of Winter Quarters Bay also may influence the accumulation of substances in the bay. Contaminants and other materials that enter the bay may remain trapped in the bay for long periods because of the isolation of the bay system. Conversely, surface water runoff entering the bay and contaminants from the landfills along the shore of the bay will tend to accumulate in the bay.

\subsection{Hydrology}

Patterns of currents in McMurdo Sound were studied by the Raytheon Company for consideration in designing new wastewater outfalls and water intakes (Raytheon 1983). McMurdo Sound, which is in the vicinity of McMurdo Station, is covered with sea ice that breaks up only for a brief period in some years and not at all in other years. Tides follow a 13-day cycle, with daily variations in the water surface elevation ranging from about 0.1 to $1 \mathrm{~m}$ through the cycle. The direction and speed of currents vary greatly over time during the tidal cycle among sites along the Ross Island coast. In general, researchers believe that a net southward flow exists in the central and eastern Sound and a northward flow exists in the western Sound (Barry and Dayton 1988). Current meters deployed offshore of McMurdo Station (Barry 1994, 1995) showed a net counterclockwise gyre (currents may reverse with the tides) (Figure 2), and occasionally the gyre reverses for extended periods. The net current speeds near the mouth of Winter Quarters Bay are only about 1 to $3 \mathrm{~cm} /$ second and the $\mathrm{B}$ and $\mathrm{C}$ meters, deployed nearest the bay, show net current speeds of $<1$ $\mathrm{cm} / \mathrm{second}$ (the period of observation was only 5 days). The only current meter ever deployed inside the bay showed such minimal current speeds that the bay can be considered practically stagnant (Raytheon 1983). While currents in the bay are generally slow, an incident of a strong current flowing from Hut Point toward and under the Ice Pier has been reported. ${ }^{\text {a }}$

a. (Paul Berkman, personal communication). 


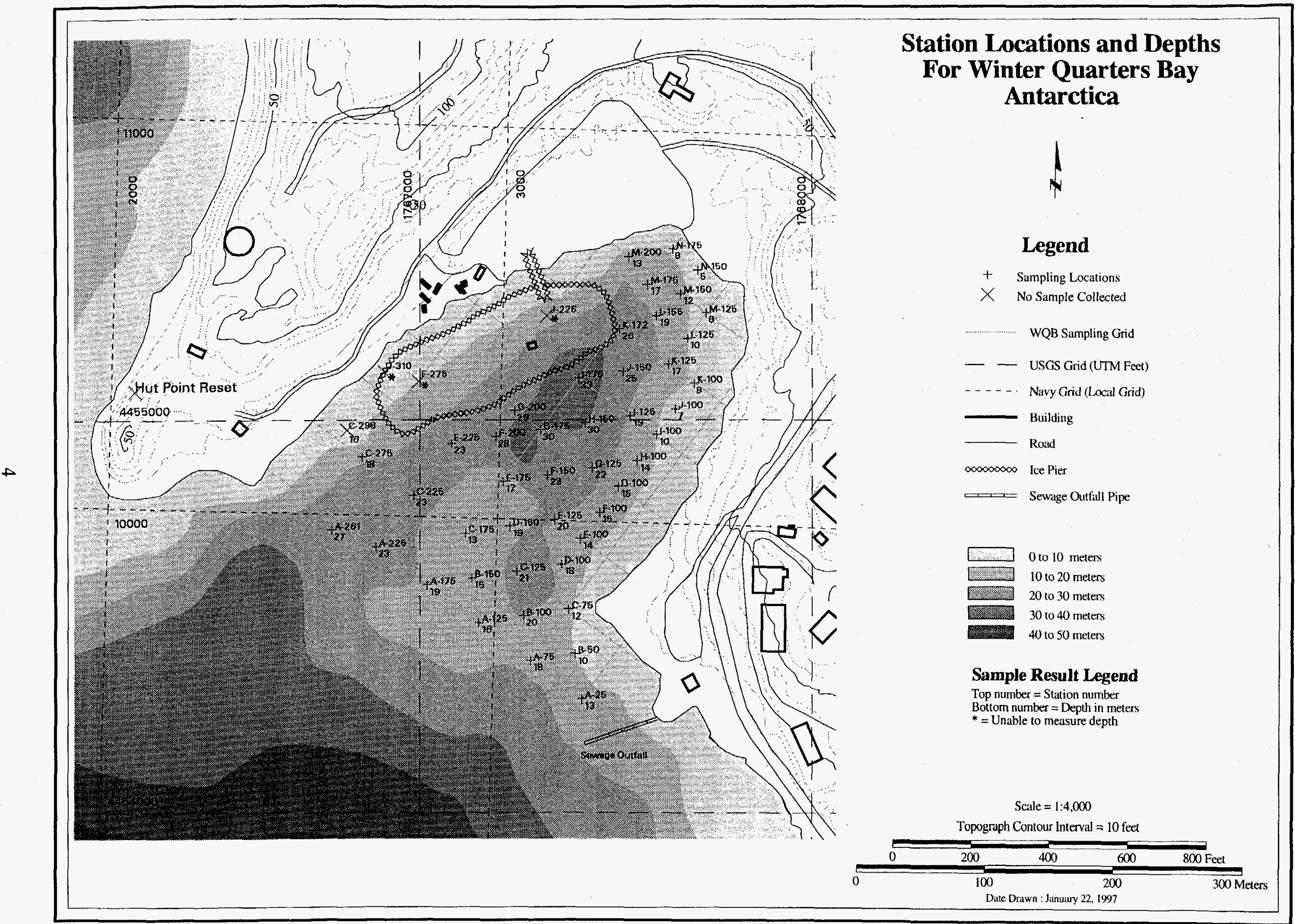

Figure 1. Station locations and depths for Winter Quarters Bay, Antarctica. 


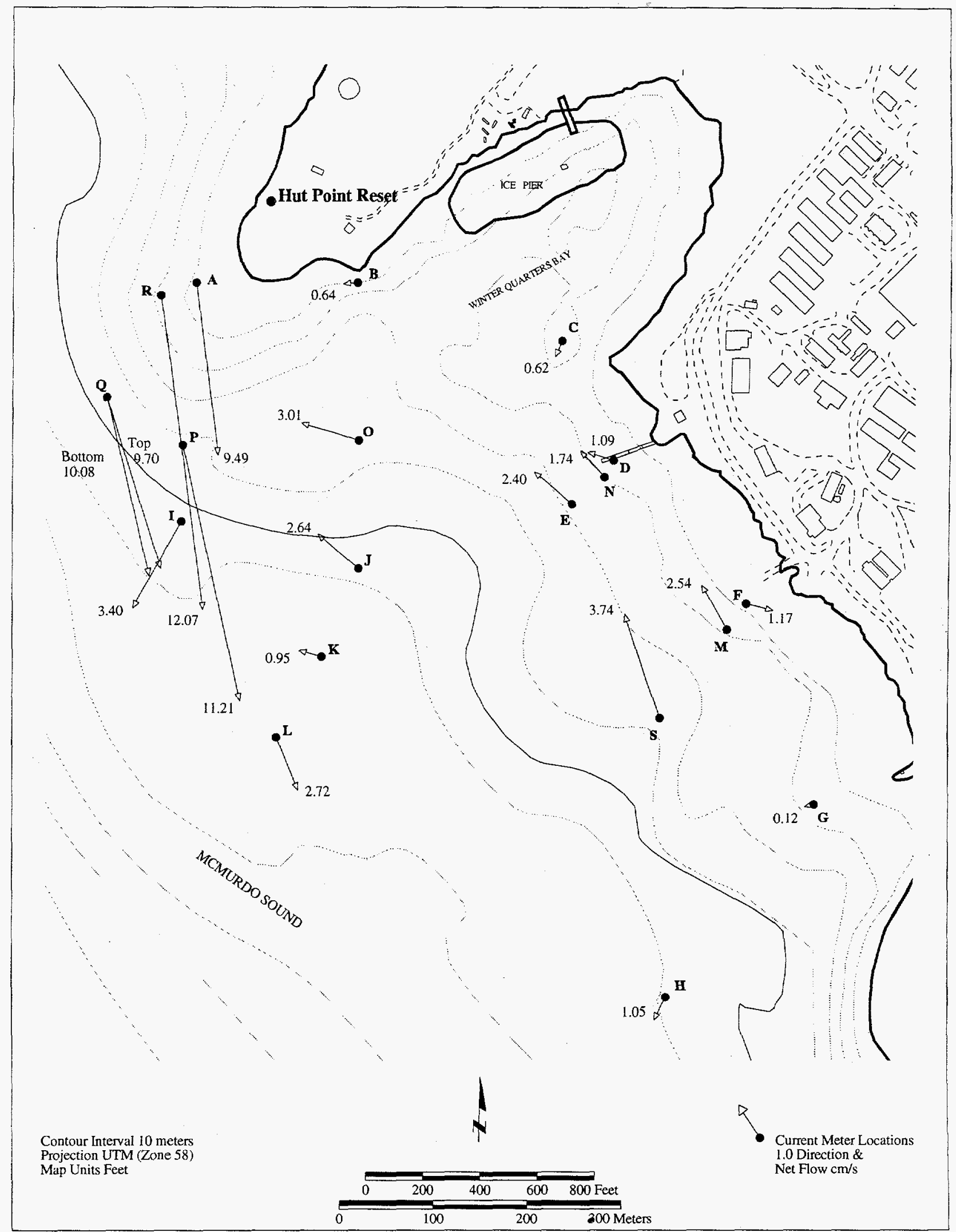

Figure 2. Mean spring/summer currents near McMurdo Station, Antarctica (Crockett 1997; Barry 1994). 
McMurdo Sound is affected by the annual formation of sea ice, and has a high salinity ( 34 to $35 \mathrm{ppt}$ ) and cold temperatures (about $-2^{\circ} \mathrm{C}$ ). Vertical variation in temperature and salinity in winter and spring is only slight, but some stratification occurs in summer (Barry 1988).

Runoff typically occurs on the relatively few days in midsummer when air temperatures and sunlight are sufficient to melt snow. Drainage at McMurdo Station is divided by the road going from Hut Point to the gap leading to Scott Base. Drainage above the road has been channeled into a ditch along the uphill side of the road. Runoff flows through the ditch until it reaches a culvert under the road, after which the drainage channel empties into the bay. This drainage includes runoff from the Fortress Rocks dump area and the hazardous waste storage yard, though drainage has generally been routed around these potential sources of contamination. Drainage from south of the road flows through several small channels, including one around the perimeter of Observation Hill and a network draining the central part of the station. These channels enter McMurdo Sound directly, not through the bay.

\subsection{Benthic Sediment Properties}

Because of low currents within Winter Quarters Bay, silt and clays have accumulated to higher levels than in most areas of similar depth around McMurdo Station. In a study of benthic marine pollution in the vicinity of McMurdo Station, median grain size, sorting coefficient, percent silt and clay, and percent organic carbon for six locations within the bay, several locations just outside the bay, and at three reference sites were observed (Lenihan et al. (1990). The percent silt and clay at the reference sites ranged from 1.6 to $8.3 \%$, while levels within the bay ranged from 21 to $68 \%$. Investigators from the INEEL mapped silt and clay levels and total organic carbon levels, as shown in Figures 3 and 4 . The concentration of fines decreased near the mouth of the bay, and samples could be collected at several sites because of the hard bottom. While the bay has relatively fine sediments, enough gravel-sized particles are present to have prevented attempts by several investigators including personnel from the INEEL to perform gravity coring of the sediments. The highest organic carbon levels were near the southeast corner of the bay, which is down current of the wastewater outfall. McMurdo wastewater is only macerated and, until the end of 1991, was discharged at the shoreline. The higher levels of carbon are presumably caused by the settling of particles from the wastewater discharge and increased benthic biomass from nutrient enrichment. 


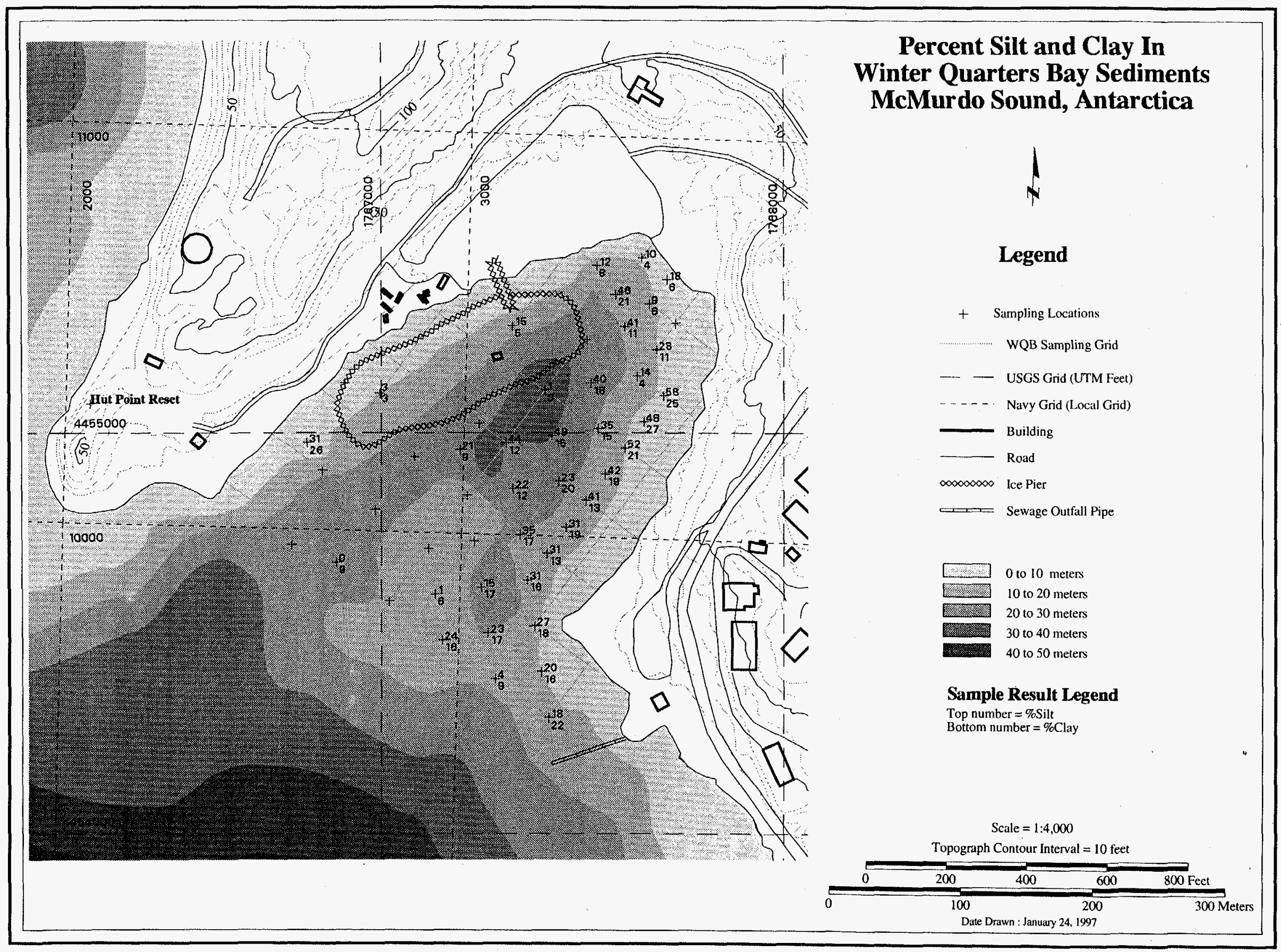

Figure 3. Percent silt and clay in Winter Quarters Bay sediments, McMurdo Sound, Antarctica. 


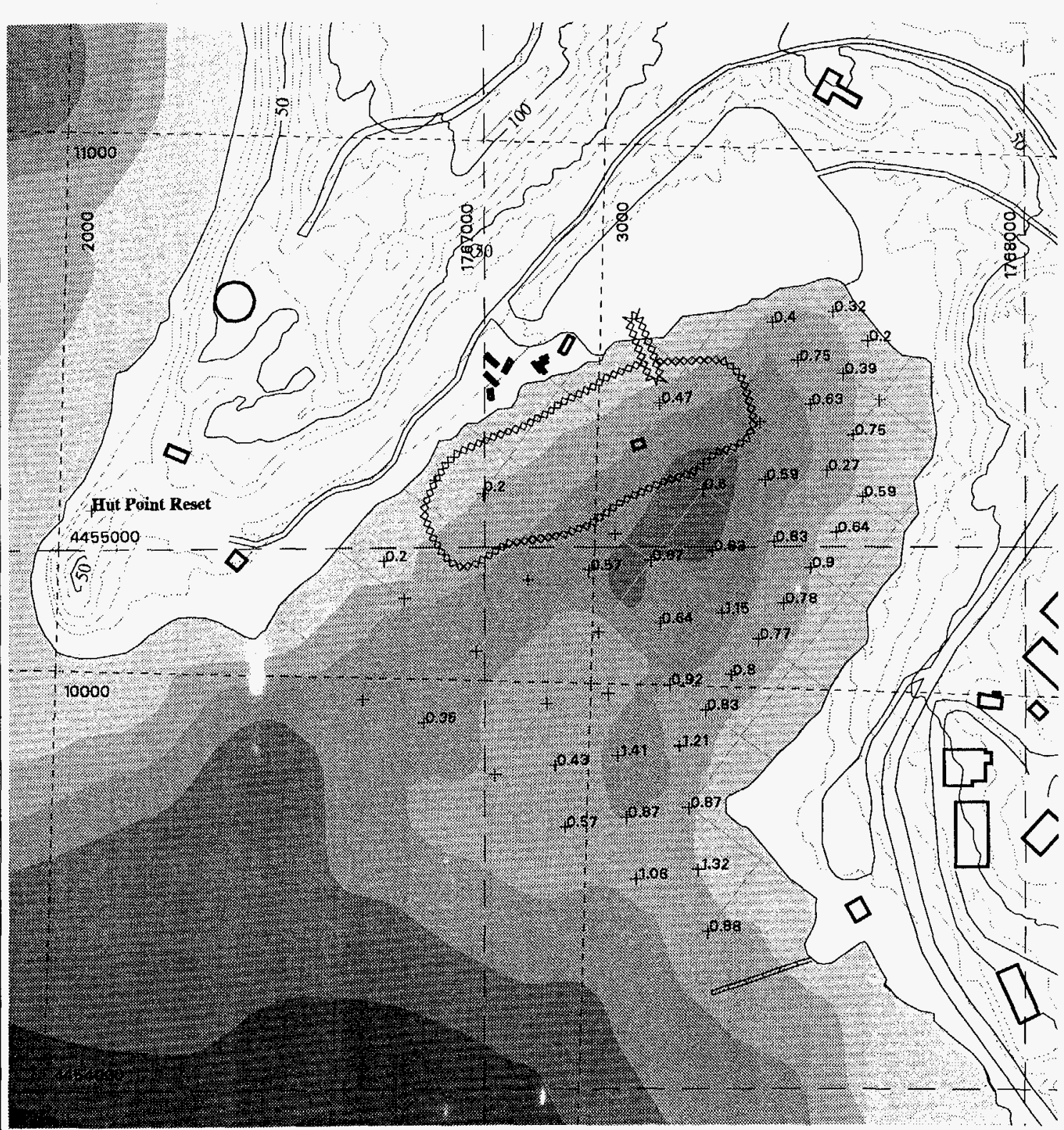

Total Organic Carbon In Winter Quarters Bay Sediments McMurdo Sound, Antarctica

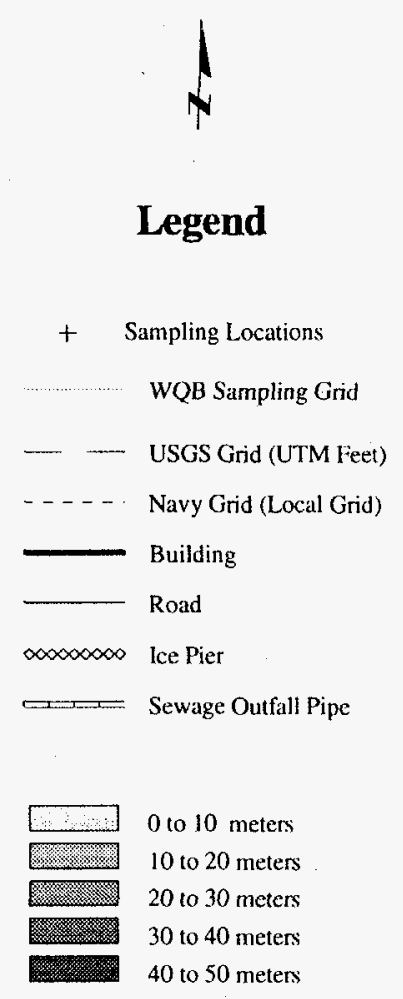

Sample Result Legend

Total Organic Carbon, \%

Scale $=1: 4,000$

Topograph Contour Interval $=10$ feet

\begin{tabular}{crrrr}
\hline 0 & 200 & 400 & 600 & 800 Feet \\
\hline 100 \\
Date Drawn : January 24,1997
\end{tabular}

Figure 4. Total organic carbon in Winter Quarters Bay sediments, McMurdo Sound, Antarctica. 


\section{ANTARCTIC BENTHIC ECOLOGY}

Information on benthic communities of the McMurdo Sound area is summarized in this section and where possible, the areas near McMurdo Station are focused on. This is done to provide a reference point with which to compare the current benthic ecology within Winter Quarters Bay and other contaminated sites near McMurdo Station with those of nonimpacted areas. Important natural disturbance processes also are described as they relate to the structure of the benthic community.

\subsection{Benthic Communities of Nonimpacted McMurdo Sound}

During Mesozoic times, present day Antarctica comprised a portion Gondwanaland, a mild, subtropical continent that broke up during the late Cretaceous Period. Following the breakup of Gondwanaland, Antarctica migrated toward the pole, where its present position enables the development of the circumpolar Antarctic current, which effectively isolates the continent (Dayton 1994). Strong convergence, divergence, and upwelling systems have since developed around Antarctica. These current systems have served to help isolate the Antarctic marine system from the rest of the world's oceans.

A second factor contributing to the isolation of the Antarctic marine system is the narrow continental shelf of Antarctica, which is effectively separated from other similar shelf habitats to the north by wide, deep zones of very cold water. Though some limited biological exchange from outside the Antarctic continental shelf may occur via the deep sea and the Scotia Arc, the combination of cold temperatures, deep surrounding waters, and the strong circumpolar currents have effectively isolated the benthos of the Antarctic continental shelf (Denton, Armstrong, and Stuvier 1971).

The Antarctic marine system contains the oldest and most isolated association of marine species in the world, and is characterized by a high degree of endemism (Dayton, Mordida, and Bacon 1994). The endemism is not consistent across phyla because most of the endemism is found within relatively few taxa (see Arntz and Gallardo 1993). At the same time, some of the most important Arctic groups of species in Arctic systems are completely absent in the Antarctic. Examples include bottom fish, and bivalves. Crabs also are absent in Antarctic waters, though considerable fossil evidence indicates that they were once abundant (Dayton, Mordida, and Bacon 1994). This results in a higher species richness and a lower ecological diversity in the Antarctic as compared with the Arctic (Table 1).

Two factors play important roles in defining benthic communities in this region in comparison with those found in other parts of the world: (1) the isolation of these communities from similar communities elsewhere and (2) the stability of the environmental conditions to which these communities are subjected.

Though the temperatures found in the Southern Ocean are cold, the physical environment is unusually stable and uniform in comparison with that of other continental shelf systems studied, including those found in the Arctic (Dayton 1990). The Arctic Ocean receives substantial inputs of fresh water from rivers flowing from North America and Eurasia, whereas the Southern Ocean receives virtually no such input. The Southern Ocean also receives relatively little fresh water input from meltwater runoff. Besides altering the salinity, this freshwater input also contains substantial quantities of nutrients and dissolved gases. Therefore, while the Arctic continental shelf systems are subject to large fluctuations in water temperature, salinity, nutrients, and dissolved gases, the waters of the Southern Ocean remain relatively constant in these respects. Thus the 
Table 1. Number of recorded benthic species for certain groups in Arctic and Antarctic regions.'

\begin{tabular}{lcc}
\hline \multicolumn{1}{c}{ Group } & Antarctic & Arctic \\
\hline Mollusks & 875 & 224 \\
Polychaetes & 650 & 300 \\
Amphipoda & 470 & 262 \\
Isopoda & 299 & 49 \\
Pycnogonid & 100 & 29 \\
Bryozoan & 310 & 200 \\
Sponges & 300 & 200 \\
Ascidians & 129 & 47 \\
\hline 1. From Grebmeier and Barry (1991), as cited in Dayton, Mordida, and Bacon 1994. & \\
\hline
\end{tabular}

waters of the Southern Ocean tend to be both stable and effectively isolated from those to the north. This combination has resulted in the development of a unique marine system (Dayton 1990).

The combination of a uniform physical and chemical environment as well as the isolation created by hydrological barriers has resulted in the development of a unique benthos throughout most of the region. Exceptions occur, however. For example, inputs of nutrients from penguin or seal colonies or of meltwater can be of local importance. On a larger scale, extreme differences were observed between the benthic communities on the eastern portion and the western portion of McMurdo Sound at Cape Armitage (Dayton and Oliver 1977). The extremes were attributed to the effects of the oligotrophic currents, originating from under the Ross Ice Shelf, along the western stretches of McMurdo Sound. Such differences seem to be the unusual exception. Virtually identical assemblages of benthic species have been noted around the entire continent.

The predominant benthic communities of the Antarctic shelf are considered to be extremely old, having developed from propagules that moved poleward along with the continent (Picken 1985). These conditions, coupled with the lack of pelagic larval stages in many of the dominant benthic invertebrate groups found in Antarctic waters (White 1984; Picken 1985), have resulted in an extremely high degree of endemism among the invertebrates (Dell 1972; Knox and Lowry 1977). The high biomass found in these communities results not from high productivity, but from the combination of slow growth, delayed maturation, and longevity (White 1984). These communities, along the eastern shore of McMurdo Sound, have been present for many thousands of years (Dayton 1989; Oliver 1984) and are relatively undisturbed by natural processes (Dayton et al. 1974; Dayton and Oliver 1977; Oliver and Slattery 1985).

The waters surrounding Antarctica are considered to be among the most productive in the world. Though there is a distinct seasonal pulse, biological productivity in the Southern ocean is high and extremely predictable. Much of this high productivity is related to the prolific krill-based food web that dominates the water column. 
By contrast, growth rates and secondary productivity levels in Antarctic benthic communities are extremely low, despite the fact that the biomass of these communities is typically very high (White 1984; Picken 1985). Benthic communities in the Antarctic and elsewhere are dependent on the nature, abundance and predictability of organic inputs; the efficiency of the organisms present in using these inputs; and the degree to which the community is influenced by disturbance phenomena (Dayton 1990).

\subsection{Natural Disturbance to Antarctic Benthic Communities}

Despite the apparent stability found in Antarctic benthic communities, physical disturbance plays an enormous role in shallow waters. This natural disturbance is dominated by two distinct ice-related phenomena (White 1984). Shallow water benthic communities are subject to physical scouring and abrasion from masses of ice floating with the tides and currents in the spring and summer. These communities are also subject to "plucking" by anchor-ice to a depth of $33 \mathrm{~m}$. Collectively, these two phenomena dictate the composition of benthic communities, preventing their establishment altogether at the most shallow depths (intertidal or immediate subtidal), and restricting the development of communities of sessile organisms to protected areas such as rocky crevices and overhangs at deeper depths (e.g., Ellis and Wilce 1961; Heine 1989; Dayton, Robilliard, and DeVries 1969; Dayton, Robilliard, and Paine 1970).

\subsubsection{Ice Scour}

In the McMurdo Sound region, ice floes from the near-by Ross Ice Shelf occasionally scrape the bottom as they move with the tides and currents during the breakup period. This scouring can occur to depths of at least $15 \mathrm{~m}$, depending on the size of the floe (Dayton, Robilliard, and Paine 1970). Though ice scouring by drifting floes will occur only rarely at any given location, the slow growth rates of benthic organisms in the region results in very long recovery periods following such a disturbance event. Even at low disturbance frequencies, sessile benthic species will be absent. Below the level of periodic ice scouring, benthic communities are dominated by sessile, particle-feeding organisms including hexactinellid sponges, desmosponges, hydroids, tunicates, polyzoans, sedentary polychaetes, lamellibranch mollusks, actinarians, scleractinian corals, and holothurians (Dayton, Robilliard, and Paine 1970). Because of their slow growth rates, these organisms cannot exist where disturbance occurs.

\subsubsection{Anchor Ice}

In the spring, large platelet ice crystals form on solid substrates at shallow depths. These crystals may grow to be up to 10 to $15 \mathrm{~cm}$ in diameter and 0.2 to $0.5 \mathrm{~cm}$ thick, effectively forming an aggregate mat along the bottom that entangles benthic organisms present on the substratum (Dayton, Robilliard, and Paine 1970). Ultimately, these organisms or abiotic objects may be ripped from the substrate and lifted to the surface as the ice formation becomes larger and more buoyant. These aggregates have been observed to lift weights of at least $25 \mathrm{~kg}$, and may, therefore, have a pronounced effect on the benthic animals (Dayton, Robilliard, and DeVries 1969). The anchor ice phenomenon is common to depths of about $15 \mathrm{~m}$, encompassing virtually any surface found to this depth. Below the $15 \mathrm{~m}$ depth, these anchor ice aggregates become discontinuous, decreasing in abundance down to a depth of $33 \mathrm{~m}$ at which they cease to form. 


\subsection{Vertical Zonation of Antarctic Benthic Communities}

The Ross Sea and McMurdo Sound provide the most southerly access to marine bottom communities, and considerable work has been done in this region. Benthos have been explored as far south as 78 degrees south latitude (Littlepage and Pearse 1962; Dayton and Oliver 1977).

As indicated above, the structure of benthic communities in McMurdo Sound and elsewhere around Antarctica are governed primarily by the pattern and severity of natural disturbances from ice scour and the formation of anchor ice. The importance of these physical stresses led Dayton, Robilliard, and Paine (1970) to characterize shallow-water benthic communities into three vertical zones. According to this scheme, Zone I consists of the communities within depths down to $15 \mathrm{~m}$, and Zone III represents the communities below 33 $\mathrm{m}$, in which anchor ice formation has not been observed. Zone II constitutes the transition area between Zones I and III. The work leading to the development of this mode of characterization was done primarily in the Cape Armitage and Hut Point areas near Winter Quarters Bay.

The shallow Zone I represents the most highly disturbed benthos, in which anchor ice forms fairly continuous mats on the substrates and in which ice scour generally occurs every year. At Cape Armitage and Hut Point, this region of regular disturbance was found to extend consistently to a depth of approximately $15 \mathrm{~m}$. Dayton, Robilliard, and Paine (1970) characterized Zone I areas as having "a general organic barrenness," in which the combination of abrasion from moving masses of ice and heavy anchor-ice formation effectively remove any life forms that become established annually. Fauna of Zone I is, therefore, characterized by motile detritus feeders and their predators. The most common life forms encountered in these areas include detritus-feeding sea urchins (Sterechinus neumayeri), sea stars (Odontaster validus), and scavengers such as nemertean worms (Parbolasia sp.). Isopods (Glyptonotus antarcticum), sea spiders (pycnogonids), and fish occasionally may be found.

The upper limit of Zone II is found at about $15 \mathrm{~m}$, and likely represents the lower level of predictable annual removal of sessile fauna by ice scouring and heavy anchor ice formation. The lower limit of Zone II is abrupt and predictable at $33 \mathrm{~m}$ (Dayton, Robilliard, and DeVries 1969). The very slow-growing sponges cannot survive for long at depths of less than $33 \mathrm{~m}$ because of the periodic disturbance. Because the frequency and severity of physical disturbance from ice phenomena decreases with depth through Zone II, a vertical gradient exists in which species diversity, abundance, and growth all gradually increase concomitantly (Dayton, Robilliard, and Paine 1970). Faunal assemblages, therefore, change gradually over an extended range through Zone II until the undisturbed, complex communities of Zone III are found. Though most of the motile fauna found in Zone I also are found in Zone II, numerous sessile animals not found in Zone I may be found in Zone II. The frequency with which these forms are encountered increases with depth through Zone II. Common species in Zone II that are not typically found in Zone I include actinarians (Isotealia antarctica, Urticinopsis antarctica, Hormathia lacunifera); stolonifera (Clavularia frankliniana); and hydrozoans (Tubularia hodgsoni, Lampra parvula). Toward the lower portion of Zone II, scattered individuals of the hydroid Halecium arboreum and occasional clumps of sponges also may appear.

As indicated above, Zone III begins abruptly at $33 \mathrm{~m}$. Ice scouring is rare (but not absent) below this depth. Although this represents a sharp physical boundary beneath which disturbance from anchor ice is absent, changes in the faunal communities are much less distinct because of the continued (but increasingly rare) disturbance from ice scouring. Zone III fauna consists of a complex sponge spicule mat community. 
This sponge spicule mat is typically at least 1 meter in thickness, and is, therefore, dominated by a vertical structure. In contrast, benthic communities in Zones I and II maintain a strictly horizontal structure. The sponge spicule mat comprises numerous intermingled sponge species along with species of mollusk as well as polychaetes and bryozoans. Species diversity is considerably higher than that found in Zones I or II. Dearborn (1965) recorded more than 12,500 individuals of an undetermined number of the various species within a cubic decimeter of the sponge mat. Feeding upon the sponges are several species of asteroids and nudibranches, which constitute the most conspicuous motile representatives of Zone III fauna. Detritus feeders also are present. The ecological organization of the benthic communities at a depth of between 30 and $60 \mathrm{~m}$ near Cape Armitage and other areas within McMurdo Sound is provided in Dayton et al. (1974).

At Hut Point, the substratum changes from cobble to one consisting of a thick mat of sponge spicules and bivalve shells over a vertical distance of only $3 \mathrm{~m}$ (Dayton, Robilliard, and Paine 1970). This change is attributed to the interaction of two related processes: (1) the suddenly abundant sponge community effectively excluding the epifauna found in Zone II and (2) the relative physical stability in Zone III allowing organic debris to accumulate, altering the substratum from a hard rocky bottom to a thick mat of sponge spicules (Dayton, Robilliard, and Paine 1970). Conditions in Zone III are extremely stable, and the faunal densities, standing crop, and trophic complexity all increase substantially over those of Zone II.

The deepest point within Winter Quarters Bay is $33 \mathrm{~m}$, indicating that even in the absence of the chemical contamination now found, the sponge spicule mat communities described for Zone III are not expected. Early work within the bay area, before extensive contamination, indicates that such communities never were present. ${ }^{b}$ 


\section{CONTAMINANT SOURCES}

This section contains summaries of qualitative and quantitative data that provide evidence on how contamination may have reached Winter Quarters Bay. Though some anecdotal information is included, most of the information in this section is based on earlier sampling activities in the bay area. Where possible, evidence is provided indicating whether the source identified remains or has been effectively removed.

\subsection{Lenihan et al., 1990}

In "Intense and Localized Benthic Marine Pollution Around McMurdo Station, Antarctica" in the Marine Pollution Bulletin, Lenihan et al. (1990) concluded that there were two possible sources of anthropogenic hydrocarbons and metals found in Winter Quarters Bay. The first was ship bilges that were historically emptied into the bay while ships were docked at the McMurdo ice pier. The second likely source was from residual burned oils and fuels deposited in the Winter Quarters Bay Landfill.

\subsection{Risebrough, De Lappe, and Younghans-Haug, 1990}

In another paper in the Marine Pollution Bulletin, Risebrough, De Lappe, and Younghans-Haug (1990) described PCB and polychlorinated terphenyl contamination in Winter Quarters Bay. The authors concluded that PCBs in sediments in the bay were derived from ship bilge or machine shop waste or both. Dichlorodiphenyltrichloroethane (DDT) compounds found in the sediments were attributed to waste from the old dump.

\subsection{Argonne National Laboratory, 1992}

A preliminary site investigation for Winters Quarters Bay Landfill was published by Argonne National Laboratory (ANL 1992). This was based on the analyses of soil samples collected from three holes and two shallow trenches ( 60 to $90 \mathrm{~cm}$ deep) in the part of the landfill known as the "Old Dump." A total of six soil samples and two water samples were collected and analyzed for a variety of parameters. All volatile organic compounds (VOCs) detected in the soil samples were fuel-related, with the exception of tetrachloroethene, which was detected in all soil samples. Water and sediment samples were also collected from two drainages flowing through the landfill area. Two VOCs detected in both sediment samples were fuel-related. Total petroleum hydrocarbons (TPH) were detected in both sediment samples, and semivolatiles and PCBs were detected in one sediment sample. TPH were detected in one water sample. A total of 18 metals were analyzed in water and sediment samples.

\subsection{Fortress Rocks Landfill}

Remediation of the Fortress Rocks Landfill was performed during the 1991-92 field season by AECOM (1992) under the direction of Antarctic Support Associates (ASA). Debris not covered with fill was sorted, packaged, and retrograded to the United States. After the waste was removed from the landfill, surface samples (from a depth of 0 to $15 \mathrm{~cm}$ ) were collected for hazardous materials analysis. No hazardous materials were found that would require additional remediation, would present a source of potential exposure 
to station personnel, or would pose an immediate migration threat. No significant levels of organic and heavy metal contaminants were present in the landfill at the depths sampled.

\subsection{Winter Quarters Bay Landfills}

Consoer Townsend Associates performed a comprehensive investigation of the Winter Quarters Bay Landfill (WQBL), former landfill, and snow dump site adjacent to Winter Quarters Bay. The site was used between 1956 and 1980 for depositing waste, debris, and snow from McMurdo Station. According to the Supplemental Environmental Impact Statement for the United States Antarctic Program (NSF 1991), the Fortress Rocks Landfill was constructed during the 1980-81 season to replace the Winter Quarters Bay Landfill. Subsequently, some cleanup of the bay landfill area occurred, and the area was covered with fill and graded.

The work involved the collection and analysis of samples to characterize the soil, sediments, and water runoff associated with Winter Quarters Bay Landfill, which culminated in the publication of a sampling and analysis report (Consoer Townsend 1995). The AECOM and Consoer Townsend work also involved the examination of existing aerial photos, maps, plans, etc. Researchers for the companies staff also conducted personal interviews in an attempt to reconstruct the history of the landfill.

In addition, the work included the collection and analysis of a total of 134 soil, sediment, and water samples. Soil samples were collected above the permafrost and ice layer. Sediment samples were from areas deposited on the shoreline or sea ice along Winter Quarters Bay by runoff or erosion mechanisms. Water samples were from snowmelt runoff during the brief runoff period (i.e., no seawater samples) to characterize contaminant transport by water through different areas of the landfill.

The results of the analysis indicated widespread hydrocarbon contamination of the Winter Quarters Bay Landfill. Geometric mean levels of $\mathrm{Cd}, \mathrm{Cr}, \mathrm{Pb}$ and $\mathrm{Zn}$ in all three sections of the landfill were above the range of background reported for McMurdo soils (Crockett 1997). Soluble and sorbed contaminants are easily transported to the bay by surface runoff including seeps and erosion. Because the dump actually continues into the bay, ice erosion of soils and sediments can result in the redistribution of contamination. The existing conditions in the landfill are not expected to improve over time because biodegradation and other attenuation mechanisms that could potentially reduce or stabilize the contaminants are extremely limited in the Antarctic environment.

\subsubsection{Sediment Samples}

Sediment samples were collected to characterize the contaminants that could readily migrate into Winter Quarters Bay. Sediment samples were collected from eight locations adjacent to the Winter Quarters Bay Landfill, two in the old dump region and six in the snow dump/original dump region. The results of the analysis of these samples are provided below:

- Volatile Organic Compounds: Headspace measurements were made on Winter Quareters Bay Landfill sediment samples using a photoionization detector. The results showed 3 to $13 \mathrm{ppm}$ VOCs. Five VOCs were detected among the eight sediment samples analyzed by gas 
chromatography and gas chromatography/mass spectroscopy. Total VOC levels ranged from 5 to $390 \mathrm{ppb}$.

- Total Residual Petroleum Hydrocarbons: Total aliphatic hydrocarbon concentrations for the sediment samples ranged from 200 to $860 \mathrm{ppm}$. Total aromatic hydrocarbon concentrations ranged from below the detection limit to $22 \mathrm{ppm}$. Total petroleum hydrocarbon concentrations ranged from 23 to $2,200 \mathrm{ppm}$, as determined by gas chromatography. The classes of petroleum hydrocarbons detected included diesel, heavy oil, and kerosene/JP-8. Heavy oil concentrations ranged from $180 \mathrm{ppm}$ to $2,200 \mathrm{ppm}$. Kerosene/JP-8 concentrations ranged from 110 to 1,700 ppm. Low levels of diesel fuel ( 35 and $23 \mathrm{ppm}$ ) were detected in two samples.

- Semivolatile Organic Compounds: Total semivolatile organic compound concentrations ranged from 260 to $8,500 \mathrm{ppb}$. Thirteen different semivolatile organics were detected in the eight sediment samples analyzed. Phthalic ester acids were the most common semivolatiles detected, with four phthalic ester acids reported. Bis(2-ethylhexyl)phthalate was detected in all eight samples at a maximum concentration of $6,200 \mathrm{ppb}$. Di-n-butylphthalate also was detected in all eight samples with a maximum concentration of $580 \mathrm{ppb}$. Six common semivolatile organic compounds that are common constituents of petroleum fuel were detected. Of these, naphthalene $(1,900 \mathrm{ppb})$ and 2-methylnaphthalene $(1,200 \mathrm{ppb})$ were detected in the highest concentrations. Polycyclic aromatic hydrocarbons (PAHs) commonly associated with combustion residues (e.g pyrene, chrysene, benzo(a)anthracene) were detected in several sediment samples at concentrations ranging from 48 to $400 \mathrm{ppb}$. Benzo(a)anthracene and chrysene were detected in two samples and pyrene was detected in seven samples.

- Polychlorinated Biphenyls: All eight sediment samples analyzed contained detectable concentrations of PCBs. Aroclor 1260 was the only congener detected in these samples, with concentrations ranging from 0.22 to $1.3 \mathrm{ppm}$.

- Metals: The geometric mean levels of $\mathrm{As}, \mathrm{Cd}, \mathrm{Cr}, \mathrm{Cu}, \mathrm{Pb}, \mathrm{Hg}$, and $\mathrm{Zn}$ were outside the background range calculated for McMurdo soils (Crockett 1997). Other metals also may be significantly elevated but background data exists for only a few elements. No sediment samples contained detectable concentrations of $\mathrm{Se}$. The $\mathrm{Pb}$ concentrations in two samples were sufficiently elevated $(2,400 \mathrm{ppm})$ to assume that aqueous leachate derived from these samples may exceed the toxicity characteristic leaching procedure and the synthetic precipitation leaching procedure limits.

\subsubsection{Water Samples}

Seven water samples were collected from surface sueans and pools upstream of and within the Winter Quarters Bay landfill. The analytical results are summarized below:

- Volatile Organic Compounds: Nine VOCs were detected in the seven water samples analyzed, with one or more BTEX (benzene, toluene, ethyl benzene and xylene) constituents detected in 5 samples. The maximum VOC concentration detected in a water sample was $30 \mathrm{ppb}$ of xylene. Two surface water samples were collected from the McMurdo River upstream and downstream of 
Winter Quarters Bay Landfill. Both samples had detectable levels of toluene (4 ppb and $1 \mathrm{ppb)}$ and xylene ( 30 and $8 \mathrm{ppb})$. These data indicate that contaminants are being discharged into the bay from McMurdo River, and that sources of organic contamination exist upstream of the landfill. Two surface water samples collected from Wharf Run at locations immediately up and downstream of the Western Snow Dump indicated trace concentrations $(<20 \mathrm{ppb})$ of the four BTEX compounds. This indicates that organic constituents are being discharged into the bay, and that sources of organic contamination exist upstream of the Western Snow Dump.

- Total Residual Petroleum Hydrocarbons: Based on a JP-8 standard, total residual petroleum hydrocarbons were not detected in the seven water samples analyzed.

- Semivolatile Organic Compounds: With the exception of detectable concentrations of di-n-butylphthalate found in two samples, no semivolatile organics were detected in the seven water samples.

- Polychlorinated Biphenyls: PCBs were not were detected in any water sample.

- Metals: The water samples were filtered and, therefore, showed only dissolved metals. Five of the eight Resource Conservation and Recovery Act (RCRA) metals were detected in the seven water samples analyzed, with $\mathrm{Ba}$ found in all samples. $\mathrm{Pb}$ was detected in four samples and $\mathrm{Hg}$ was detected in three. As and Se were detected in one sample each. The up- and downstream samples from the McMurdo River had comparable levels of metals including $\mathrm{Pb}$ ( 2.8 and $2.2 \mathrm{ppm}$, respectively) and $\mathrm{Zn}(16$ and $14 \mathrm{ppm})$. The upstream and downstream samples from Wharf Run had comparable levels of metals, including one metal of concern, $\mathrm{Zn}$, at 8.2 and 14 ppb respectively. 


\section{BENTHIC ECOLOGY AND ECOLOGICAL STRESS IN WINTER QUARTERS BAY}

This section summarizes what is known about the impacts to the benthic ecology of the Winter Quarters Bay area from human activities at McMurdo Station. Section 5.1 presents the historical information about the benthic communities that at one time inhabited the bay. Historical information from sampling efforts within the bay are summarized. By way of contrast, data on the current status of benthic communities in the bay area and adjacent impacted areas is also provided in Section 5.1. A discussion of ecological stress to the benthic communities in the bay from human activities at McMurdo Station is provided in Section 5.2. Human impacts are then compared with natural disturbances (Section 5.3), and the recovery of the bay's benthic communities is discussed (Section 5.4).

McMurdo Station represents the largest human intrusion in Antarctica, with more than 1,000 people present during the peak summer season. Over 20 years ago, concern over the potential impacts to marine communities from pollutants generated at McMurdo Station was expressed. Cameron (1972, p. 277) described Winter Quarters Bay as "notorious for the dump on the beach and approach to the station...(where) garbage, other refuse, and station debris pile up on the beach and on the adjacent ice during the winter months ... until after midsummer (when) the ice breaks up and part of the dump floats out to sea."

In the early 1970 s, concern for Winter Quarters Bay focused on the potential organic enrichment to the benthos resulting from the introduction of food waste and sewage to the near-shore waters (Dayton 1972). Much information from temperate latitudes is available on the responses of benthic invertebrate communities to organic enrichment of sediments from sewage and industrial discharges (e.g. Boesch 1982; Swartz et al. 1986; Gray et al. 1990). Such organic enrichment typically results in shifts in community structure away from resident species and toward higher proportions of opportunistic species with short generation times and good colonizing ability. Similar shifts have been observed in areas receiving chronic exposure to oil (e.g., Sanders et al. 1980; Davis and Spies 1980; and Spies, Hardin, and Toal 1988) and oil spills (e.g., Grassle and Grassle 1974; Sanders et al. 1980; Fleeger and Chandler 1983; Davies et al. 1984; Foster et al. 1988). However, most of the studies conducted to date have been conducted in temperate latitudes rather than in polar climates (e.g., Cross and Thompson 1987).

The history of human activities at McMurdo Station exceeds 40 years, during which time concern about pollutant discharges to the marine system from the station expanded to include several classes of toxic pollutants. Near-shore sediments are now known to be contaminated with relatively high levels of hydrocarbons, PCBs, and metals. This contamination has been characterized as forming a steep localized gradient of marine pollution, where physical and chemical changes have been observed in the sediment (Lenihan et al. 1990; Risebrough, De Lappe, and Younghans-Haug 1990). The most heavily contaminated habitats along this gradient are within the bay (Dayton 1989). These highly contaminated areas are restricted, however, and dense aggregations of unique Antarctic bottom communities may be found less than $1 \mathrm{~km}$ away (Dayton, Robilliard, and Paine 1970, 1974; Oliver and Slattery 1985). 


\subsection{Historical Information on Benthic Communities in Winter Quarters Bay}

Though considerable information is available on benthic communities of nonimpacted areas of McMurdo Sound, information on Winter Quarters Bay benthos prior to the onset of impacts from the development of McMurdo Station is not available. According to Dr. John Dearborn, ${ }^{c}$ benthic fauna in the bay was not rich, though he found hydroids, bryozoans on rocks, Clavularia on the bottom even within the area during the 1959-60 field season. From recently published reports, these species appear to be absent now. He also observed large areas without thick accumulations of fine sediments overlying the basaltic gravel in the bay. These early studies used underwater cameras and dredge samples to observe the bottom from the sea ice surface. Using these techniques, enough of the bay area was observed to conclude that the current status of the area is not the same as it was 30 to 35 years ago.

As early as the late 1960s, concerns were expressed about the heavy contamination accumulating in the bay because of activities at the Station (Dayton 1969, 1972; Cameron 1972). The initial concerns were with the potential impacts to benthic communities in the bay from organic enrichment. Before the outfall was moved further offshore in 1991, the sewage discharge likely flowed along the shore and along the tidal cracks, and entered the bay. Toxic materials also have accumulated in the bay (see Section 5.2). Because background data is limited at best, the evaluation of the impacts potentially from contamination to benthic communities from McMurdo Station must rely largely upon post-impact sampling.

There are some subtle differences in the benthic habitat of Winter Quarters Bay in comparison with other areas nearby, and these differences may have had a profound effect on the structure of benthic communities even in the absence of anthropogenic contaminants. The waters of the bay remain somewhat isolated from other waters within McMurdo Sound primarily because of the physical setting of the bay. The bay is somewhat sheltered from the strong currents found in the area by a substantial submarine ridge on one side and by Hut Point on the other, which reduces the transport of sediments into and out of the bay. This isolation tends to reduce the amount of contamination exiting the bay and thus limits the spread of contamination. However, the setting also causes the pollutants that enter the bay to accumulate in the bay's benthic sediments. This isolation also permits the accumulation of relatively fine sediment within the bay. Collectively, these circumstances create a unique habitat and the development of a benthic community that is different from that found in other nearby areas outside the bay.

The uniqueness of Winter Quarters Bay was illustrated by a conductivity, temperature, and depth (CTD) profile conducted by INEEL personnel in December 1993. A cast over the deepest region of the bay showed an increase in salinity and a decrease in temperature, $\mathrm{pH}$, and dissolved oxygen below a depth of about $23 \mathrm{~m}$ (Crockett 1994). These changes appear to be related to the presence of a unique brine pool in the lower portion of the bay, and provide further evidence on the isolation of waters in the bay.

Though Lenihan and Oliver (1995) concluded that the precontamination benthic communities in the bay were probably similar to those in the less contaminated or uncontaminated areas within the region, the conclusion is somewhat speculative. The combination of the unique physical setting and the differences in

c. Personal communication. 
various physical and chemical parameters noted above indicate that the benthic habitat within the bay is dissimilar to that of surrounding areas, and that the benthic communities may, therefore, have been unique within the Bay prior to construction of McMurdo Station.

The relative isolation of the bay also may serve to protect the deeper benthos from ice scouring. Furthermore, though the deepest location within the bay is $33 \mathrm{~m}$, implying that anchor ice may theoretically form anywhere within the bay, the increased salinity observed at lower depths may prevent anchor ice formation in some areas. These unique characteristics could have allowed for the development of a community of sessile benthic organisms within the bay at shallower depths than are found at other locations within McMurdo Sound, but pollutant discharges from McMurdo Station may have eliminated any such organisms. Taken one step further, these differences may have resulted in the development of a unique benthic community, unlike those found in surrounding, nonimpacted areas.

Historical evidence indicated the existence of earlier benthic communities in Winter Quarters Bay. Dense beds of dead shells from the suspension feeding clam Laternula elliptica were observed on the sediment surface in 1974 (Robilliard and Busdosh 1981). This mollusk is widespread in McMurdo Sound, and is typically found wherever the substrate is sandy. The species is found always in association with dense infaunal communities of crustaceans and polychaete worms (Dayton and Oliver 1977; Oliver and Slattery 1985). However, no evidence of dense beds of Laternula was observed in the bay during the late 1950s. ${ }^{d}$

Though Lenihan and Oliver (1995) speculate that if L. elliptica was once common in the bay, dense infaunal communities like those at Cape Armitage, Cinder Cones, and other areas where the mollusk is found, were probably present as well. However, the relative importance of this species in the benthic community prior to disturbance it is not known with certainty because the remains of these species are not preserved as readily as the clam shells.

Recent observations of Winter Quarters Bay fauna describe the benthic communities as being low in abundance of both infaunal and epifaunal organisms, with these organisms being restricted to motile, opportunistic polychaete worms (Lenihan et al. 1990; Lenihan and Oliver 1995). These were primarily Capitella capitata antarcticum, Ophryotrocha claparedii, and Gyptis sp.

\subsection{Ecological Stress in Winter Quarters Bay}

The potential anthropogenic effects on ecological communities in Winter Quarters Bay are associated both with toxic contaminants and with solid waste. For many years, solid waste was placed on the ice surface as a disposal method, which resulted in the accumulation of large quantities of waste materials in and around the bay. The best quantification of the extent of anthropogenic debris in the bay area is provided by Lenihan et al. (1990), who conducted underwater photographic transects of the area. The impact of the accumulation of solid waste in the bay on benthic communities is uncertain.

Sediments of the bay are generally mixed with a thick, oily residue of unknown substance. This material may constitute a physical barrier to some benthic life forms, either by effectively preventing

d. J. Dearborn, personal communication. 
organisms from attaching to the substrate or by effectively "smothering" them. These materials have not been thoroughly characterized for potential toxic constituents.

Though a full characterization of the potentially toxic constituents of bay sediments has not been performed, nearshore sediments are known to be contaminated with elevated levels of a variety of toxic organic and inorganic contaminants. PCBs have been found ranging from 100 to $1,400 \mathrm{ng} / \mathrm{g}$ dry weight, with the highest concentrations found in samples collected near the former dump site along the shoreline of the bay (Risebrough, De Lappe, and Younghans-Haug 1990). These concentrations were two orders of magnitude higher than for sediment samples collected at Cape Armitage ( $1 \mathrm{~km}$ distant), and three to four orders of magnitude higher than from samples collected at Turtle Rock and Cinder Cones (9 and $15 \mathrm{~km}$ distant). In the same study, chlorinated terphenyls were found in a range of 30 to $1200 \mathrm{ng} / \mathrm{g}$ in bay sediment samples. DDT compounds also were encountered at concentrations approximately an order of magnitude higher than for samples collected at other sites near McMurdo Station and two orders of magnitude higher than those found in sediments collected at Turtle Rock or Cinder Cones. Levels of purgeable hydrocarbons in bay sediments were as high as 4,500 ppm, and the concentrations of various toxic metals were also found to be high (Lenihan et al. 1995).

The elevated concentrations of these materials have been attributed to past waste discharge and to migration from the former dump site on the shore of Winter Quarters Bay. By assuming a representative value of $500 \mathrm{ng} / \mathrm{g}$ of PCBs in the top $10 \mathrm{~cm}$ of the bay, Risebrough, De Lappe, and Younghans-Haug (1990) estimated the total burden of these substances within bay sediments to be approximately $4 \mathrm{~kg}$. They concluded that global sources represented insignificant contributors to the PCB and polychlorinated terphenyl load, and that it was more likely that these contaminants originated from machine shops on board ships docking in the bay or from the machine shop located at McMurdo Station.

The concentrations of some of the toxic materials observed in sediment samples from the bay are sufficiently high to potentially impact benthic communities. Lenihan et al. (1990) concluded that both the sediments and the animals that live in and on these substrates have been "highly modified by human activities" at McMurdo Station. Of special concern were the areas adjacent to the former dump site and the ice dock used by visiting ships. They observed significant negative correlations between the total number of infauna or epifauna and the concentrations of hydrocarbons and most metals in sediments within the bay.

The most thorough examination to date of the probable impacts of marine pollutants to benthic communities in the Winter Quarters Bay area is provided by Lenihan and Oliver (1995). These workers described dramatic changes in the structure of marine benthic communities along a gradient of anthropogenic hydrocarbon, metal, and PCB contamination around McMurdo Station. Benthic marine communities were found to have changed dramatically along the pollution gradient originating in the highly contaminated bay, through a transition zone, to nonimpacted areas of "natural" communities outside the bay.

According to Lenihan and Oliver (1995), benthic communities in the highly contaminated bay area were low in abundance of both infauna and epifauna. These areas were dominated by a very limited number of species of polychaete worms (Capitella spp., Ophryotrocha claperedii, Gyptis sp.), each of which possesses a relatively opportunistic life history. They further point out that these genera are commonly found in polluted temperate marine habitats that have become organically enriched by human activities (Grassle and Grassle 1976; Aschan and Skullerud 1990). 
A distinct transition zone was observed between the highly contaminated Winter Quarters Bay and the uncontaminated end of the defined pollutant gradient (Lenihan and Oliver 1995). The benthic communities of this transition zone were dominated by motile polychaete species such as Tharyx sp. and Haploscoloplos kerguelensis and the anthozoan Edwardsia meridionalis. Though related to the species described above for the bay area, these species are considered to have somewhat less opportunistic life histories. The transition area includes the wastewater outfall area, where the same intermediately opportunistic species were found (Lenihan and Oliver 1995). They described the outfall area as being ecologically distinct from the other intermediate locations along the contamination gradient because of low total infaunal abundance and larger populations of Capitella spp., Ophryotrocha claperedii, Gyptis sp., Tharyx sp., and Haploscoloplos kerguelensis. The community structure here appears to be shifting toward that of the contaminated end of the gradient.

Farther distant along the gradient in uncontaminated sedimentary habitats, dense tube mats of infaunal species were found, dominated numerically by populations of polychaete worms, crustaceans, and a species of large suspension feeding bivalves. These species are generally large and relatively sessile, except for several crustacean species living among the tubes.

At the uncontaminated end of the gradient, benthic communities were found to have higher total abundance and diversity of species, and nonopportunistic life histories (Lenihan and Oliver 1995). Species found in the uncontaminated areas included tube-dwelling polychaetes, and suspension feeding infaunal anemones and bivalves. At Cape Armitage and Cinder Cones, benthic communities were dominated by Spiophanes tcherniai and Myriocheleheeri.

In summary, the most evident changes in community structure along the pollution gradient described by Lenihan and Oliver (1995) were increased frequencies of polychaete worms with relatively opportunistic life histories and simultaneous decreases in sedentary or suspension feeding groups as the levels of contamination increase. The opportunistic species that dominate Winter Quarters Bay are relatively small animals with short generation times, high proportions of ovigerous individuals, high larval availability, and good colonizing ability. The dominant species in relatively uncontaminated areas are not opportunistic, while many of the dominant species within the transition zone are intermediate in this respect.

Community patterns observed in the benthos along the McMurdo Sound pollution gradient are similar to those associated with other human disturbances including organic enrichment and oil spills, as well as within experimental organic enrichments and natural oil seeps (Lenihan and Oliver 1995). Though environmental conditions other than contaminant levels vary along the gradient, none can adequately explain the dramatic changes observed in the benthic communities from the bay through the transition area and to the contaminated areas. Lenihan and Oliver (1995) conclude that the native communities in Winter Quarters Bay were destroyed 20 to 30 years ago, and have been replaced by the polychaete "weeds."

Lenihan et al. (1995) conducted a series of studies using sediments collected in and around the bay. These studies included a standard laboratory bioassay, field bioassays, laboratory behavioral bioassays involving habitat selection, burrowing, and swimming, field behavioral bioassays, and a l-year community transplant experiment in the field. 
Mortality rates were found to be highest in organisms exposed to sediments collected within the bay, and generally decreased with increasing distance from the bay. Survival of Heterophoxus videns and Monoculodes scabriculosus was lowest in those organisms exposed to sediments collected from the bay, and also was greatly reduced for those exposed to sediments collected near the wastewater outfall. After 1 year of exposure on the sea floor, most of the animals transplanted to the bay disappeared, probably through emigration or death. These transplanted communities lost nearly all crustaceans and became numerically dominated by the opportunistic polychaete Ophryotrocha claperedii, one of the few species observed to live in the highly contaminated sediments of the bay.

Motile organisms such as amphipods, tanaids, and cumaceans consistently avoided sediments from the bay. In the laboratory, $H$. videns consistently avoided contaminated sediments in the habitat choice experiments. More motile organisms burrowed into the clean sediments than the bay sediments.

The studies suggested the following (Lenihan et al. 1995):

- Survivorship is reduced and behavioral patterns are more modified in contaminated sediments compared with uncontaminated sediments in standard bioassays and several field and laboratory experiments

- Communities transplanted along the contamination gradient changed to resemble the local communities to which they were transplanted.

\subsection{Comparison with Natural Disturbance}

In a recent study, Lenihan and Oliver (1995) contrasted the impacts to the benthic communities around McMurdo Station from chemical contamination with the impacts resulting from the two common forms of natural disturbance in the area: iceberg grounding and anchor ice formation. This study used the same sampling stations described by Lenihan et al. (1990) and Risebrough, De Lappe, and Younghans-Haug (1990). Natural disturbance was found to result in similar patterns of community change as those observed along the pollution gradient. Areas of severe disturbance were low in total infaunal abundance, and were colonized by motile species with highly opportunistic life histories. Areas of intermediate disturbance were dominated by species with intermediate life history patterns, while undisturbed communities had high infaunal abundance and species density.

The same motile, opportunistic polychaetes (Tharyx sp., Haploscoloplos kerguelensis and Polygordius sp.) were the most abundant in areas in which anchor ice freezing and uplift were the most prevalent and severe. Undisturbed areas contained the same dense tube mat community and large bivalve population described above. Similarly, the more recent ice gouges contained large numbers of the motile, opportunistic polychacte worms of the same species. In a related experiment, these same opportunistic species were the first to colonize sediments artificially placed on the sea floor (Lenihan and Oliver 1995). 


\subsection{Recovery of Winter Quarters Bay Benthic Communities}

Though the community patterns associated with anthropogenic and natural disturbances were found to be similar, it should be remembered that the overall area of sea floor impacted by natural disturbances vastly exceeds that impacted by human activities. In addition, human-caused impacts to the benthic communities may differ from those caused by natural phenomena in the postdisturbance recovery phase.

Even in noncontaminated areas, recovery from disturbance can be a slow process. Colonization experiments on clean sediments indicated that dense populations of infaunal crustaceans and polychaetes could take a decade to develop. However, large suspension feeding bivalves may require substantially more time to recover.

Predictions of recovery rates for the contaminated areas is complicated by the lack of information available on the reduction of toxicity within the contaminated sediments, and the return of these sediments to a more natural state (Lenihan and Oliver 1995). Persistence of the toxic constituents may substantially delay the recovery of bottom communities within Winter Quarters Bay. Degradation of hydrocarbons occurs very slowly at the $-1.8^{\circ} \mathrm{C}$ water temperatures of McMurdo Sound, and the toxic substances associated with the hydrocarbons are, therefore, likely to take decades to dissipate. An additional factor is the characteristically low natural sedimentation rates in the area, which likely will work in combination with the low degradation rates to increase the recovery time for the benthic communities, even if the source of contamination is shut off completely (Scherrer and Mille 1989; Leahy and Colwell 1990; Delille and Vaillant 1990). 


\section{CONTAMINATION IN WINTER QUARTERS BAY}

\subsection{Early Investigations}

Early reports of marine contamination around McMurdo Station discussed the station in general and did not focus on Winter Quarters Bay. However, a report by Dayton and Robilliard (1971) discussed inorganic litter on sediments around McMurdo Station and can be assumed to apply equally to the bay. They reported from inspections in 1967 to 68 that "inorganic litter on the bottom at McMurdo is dramatic: fuel lines, barrels, honey buckets, rope, clothing, tractors, pieces of airplanes, thousands of beer cans and many other types of trash are everywhere." They pointed out that though the litter is an eyesore, it probably has not seriously damaged benthic biota and the most serious effect was the covering of the bottom, which eliminates all sponges. The debris covering the bottom was expected to degrade very slowly if at all. While concern for contaminants including sewage was expressed, no data were collected on chemical contaminants.

In 1974, Robilliard and Robilliard (1981) observed and photographed a large bed of clam shells on the surface of bay sediments. The shells were piled several deep over the surface of the bottom and covered an area about $75 \mathrm{~m}$ long by $25 \mathrm{~m}$ wide at a depth of $25 \mathrm{~m}$. "The surface sediment was reddish-brown to light brown silt, but subsurface sediments were black and smelled strongly of petroleum hydrocarbons." Sediment samples were subsequently collected, analyzed, and determined to contain approximately $0.23 \%$ petroleum hydrocarbons by dry weight of sediment. The hydrocarbons appeared to be lubricating oil and possibly heavy residual or Bunker $\mathrm{C}$ fuel rather than diesel fuel. The mechanism of contamination was not determined, but the clam bed was directly under the area in which tankers offload fuel for McMurdo. When the site was revisited in 1978, the community was unchanged, and the smell of oil on the sediments was still strong.

Raytheon (1983) conducted a series of studies around McMurdo Station in 1982. The studies included determining bathymetry, measuring currents, collecting water and sediment samples for chemical and physical measurements, collecting hydrographic data, measuring pressure to determine tidal cycling, and releasing a dye to track water movement. However, only the dye study and current meter study included measurements in Winter Quarters Bay. These measurements showed very slow currents and poor mixing in the southeast corner of the bay.

\subsection{Moss Landing Marine Laboratories}

The first comprehensive studies of chemical contamination in Winter Quarters Bay were conducted by Lenihan et al. (1990) and Risebrough, De Lappe, and Younghans-Haug (1990). Lenihan et al. (1990) collected sediment samples (comprising haphazardly selected surface scrape samples from the top $5 \mathrm{~cm}$ ) from 10 locations within the bay (Figure 5) and reported on the levels of metals, percent organic carbon, percent organic nitrogen, nivdian grain size, percent silt and clay, total purgeable hydrocarbons, percent coverage of anthropogenic debris, total infauna, and metal levels in fish tissues and a worm. These data were compared to samples collected along a gradient away from the bay and to samples from reference sites. Risebrough, De Lappe, and Younghans-Haug (1990) received sediment samples from most of the same locations and analyzed them for PCBs and PCTs. Analytical data on the samples collected from and just outside of the bay are summarized in Table 2. The two studies clearly demonstrated that concentrations of some metals (Ag, $\mathrm{Cd}, \mathrm{Cu}, \mathrm{Pb}, \mathrm{Hg}$, and $\mathrm{Zn}$ ) and some organics (purgeable hydrocarbons, $\mathrm{PCBs}$, polychlorinated terphenyls, and DDT residues) are elevated within bay sediments compared to reference sediments. 


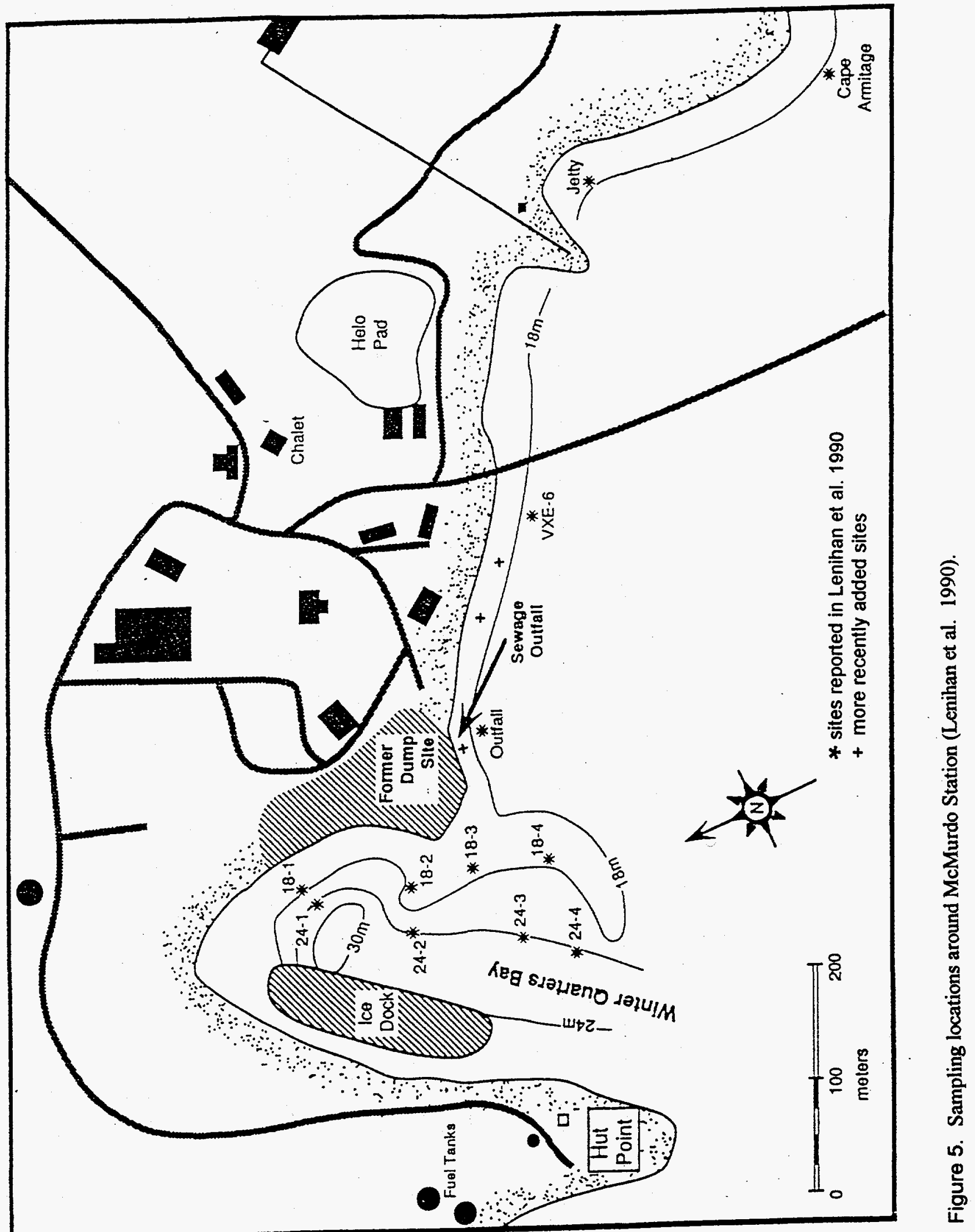


Table 2. Summary of analytical data on sediments collected by Moss Landing Marine personnel, Winter Quarters Bay and reference sites (Lenihan et al. 1990; Risebrough et al. 1990; MLML 1994).

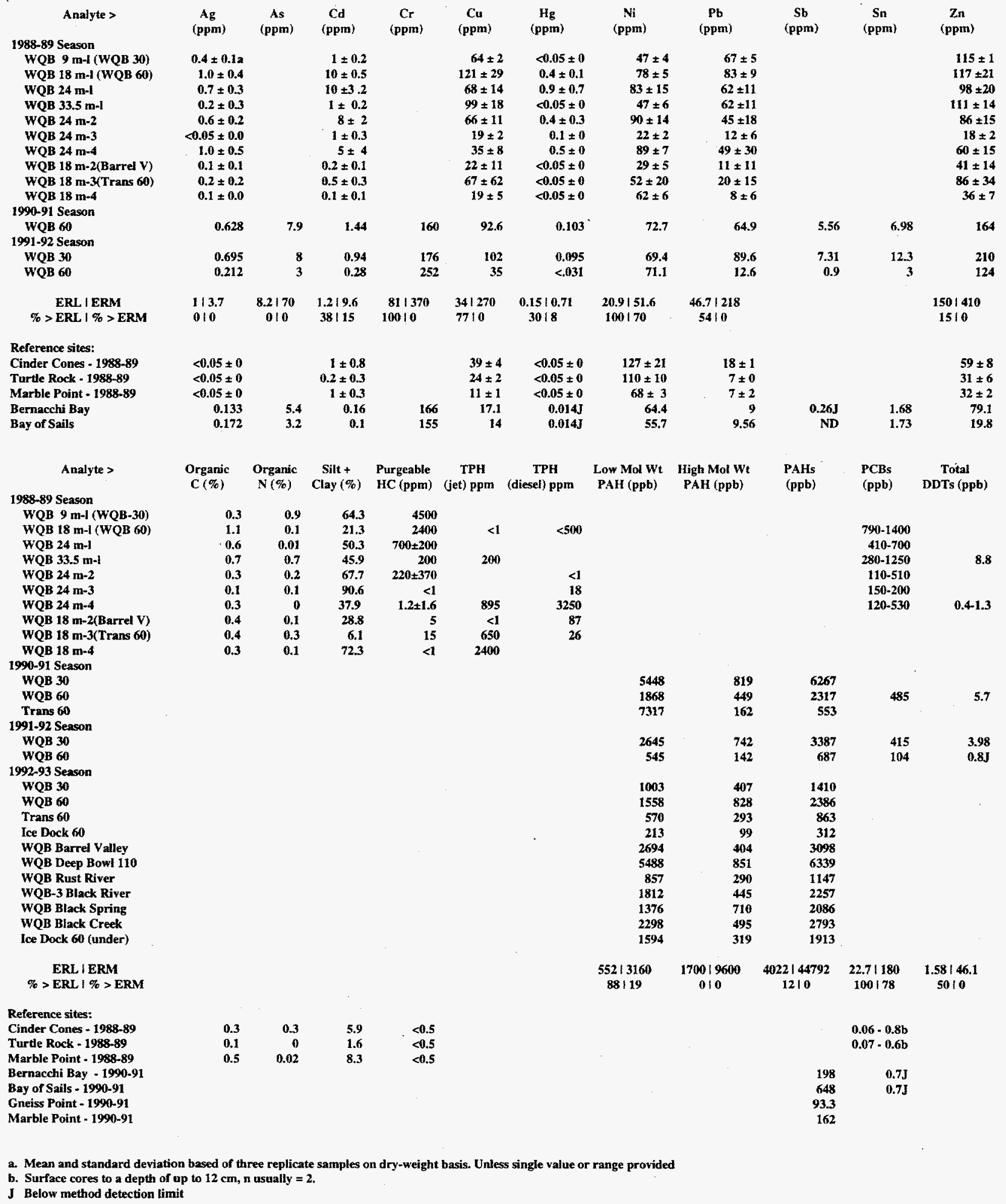


Personnel from Dr. John Oliver's group at Moss Landing Marine Laboratories (MLML) subsequently collected more sediment and biota samples from the Winter Quarters Bay, along the contaminant gradient from the bay to Cape Armitage and from reference sites (Figure 6). Results from analyses of these samples are presented in Biological Impacts of Anthropogenic Disturbances to Marine Benthos Near McMurdo Station, Antarctica; Benthic Monitoring Program 1988-1993 Data Report (MLML 1994). Additional samples were collected during the 1993-94 season, but the data were not available for preparation of this report. Analytical data on sediments in the bay (Lenihan et al. 1990; Risebrough, De Lappe, and Younghans-Haug 1990; MLML 1994) are summarized in Table 2. No technical report has been prepared on the more recent Moss Landing data though some of the more recent data were cited in a 1995 review of human contamination of the Antarctic marine environment (Kennicutt et al. 1995).

The Winters Quarters Bay data were reviewed to determine whether significant trends could be detected. For metals, only one site, WQB 60, had been sampled three times (Table 2). Levels of $\mathrm{Ag}, \mathrm{Cd}, \mathrm{Cu}$, $\mathrm{Hg}$, and $\mathrm{Pb}$ showed a consistent decrease while $\mathrm{Zn}$ levels do not appear to have changed. WQB 30 has been sampled twice for metals, and the levels of most metals were higher in the 1991-92 season than in the 1988-89 season. For PAHs, only one site, WQB 30, was sampled three times. Low and high molecular weight PAHs as well as total PAH decreased consistently through the three samplings. No such trend is apparent for WQB 60. The only site with 3 years of PCB data is WQB 60, and the apparent trend is to lower concentrations. There are, however, too few results to draw any significant conclusions about changes in the contaminant levels within the bay.

Lenihan et al. (1990) also reported on the concentrations of trace metal in fish tissues (Trematomus hansoni and T. bernachii) and a nemertean worm (Parbolasia corrugatus) from two sites in the bay and a reference site. The concentration of trace metals in the fish and worm completely overlapped the values from the Cinder Cones reference site. Samples of mollusk ( . elliptica) and fish ( $T$. bernachii) (which is the best estimate of species) were collected from one site in Winter Quarters Bay and reference sites during the 199192 season. Two of the three mollusk samples have similar levels of metals and organics while the third had much higher levels of PCBs and much lower levels of some metals (Table 3). If Winter Quarters Bay replicate sample number three is considered an outlier, the data provide some evidence that $\mathrm{As}, \mathrm{Cu}, \mathrm{Fe}$, and $\mathrm{Pb}$ levels are higher in bay mollusk samples than the reference samples. PAH levels are somewhat higher for bay mollusk samples than the reference samples. PCB levels for L. elliptica in the bay are obviously elevated by more than an order of magnitude compared to reference sites with one sample containing $6,250 \mathrm{ppb}$ of PCBs. For the T. bernachii samples, the differences in the concentrations for some metals such as $\mathrm{Cd}, \mathrm{Cu}$, $\mathrm{Ni}, \mathrm{Pb}, \mathrm{Se}$, and $\mathrm{Zn}$ are large. However, without replicates, whether these differences are significant cannot be determined.

While metal and organic contaminant levels in Winter Quarters Bay sediments have been compared to levels at reference sites and studies have concluded that bay sediments are toxic, no studies have been conducted to determine which, if any, contaminants are causing adverse toxic impacts. One simple approach is to compare contaminant levels to sediment quality criteria. Long et al. (1995) used the National Status and Trends program methodology of the National Oceanic and Atmospheric Administration (NOAA) to develop effects range-low (ERL) and effects range-medium (ERM) criteria for contaminants in bulk marine sediments. The probability of adverse impacts is high above the statistically derived ERMs, and the probability of adverse impacts is low below the ERLs. Between the two levels, adverse impacts are occasionally observed. Table 2 


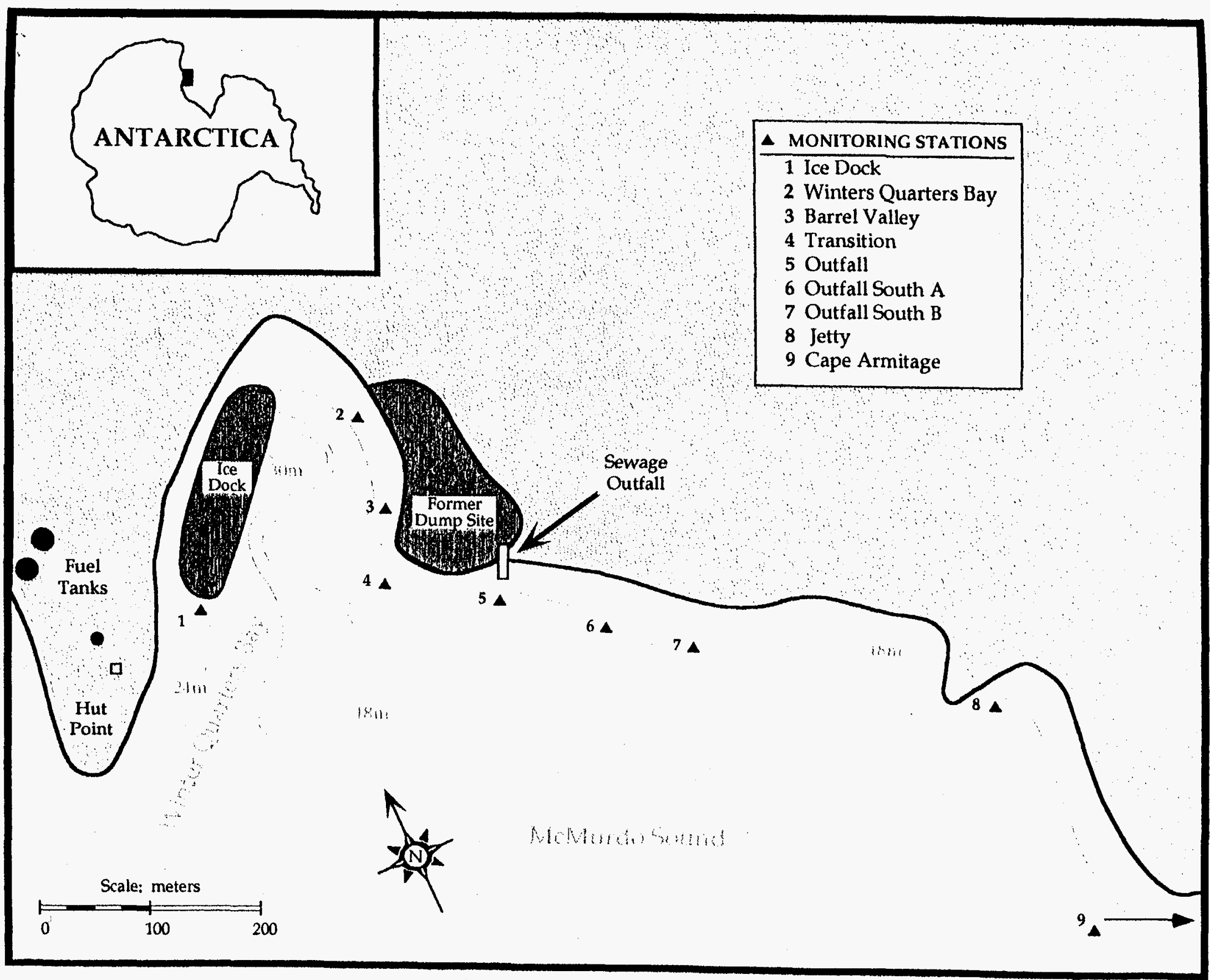

Figure 6. Routine benthic monitoring station locations, McMurdo Station, Antarctica (MLML 1994). 
Table 3. Summary of metals (ppm) and organic compounds (ppb) in biota samples from Winter Quarters Bay and reference sites (MLML 1994).

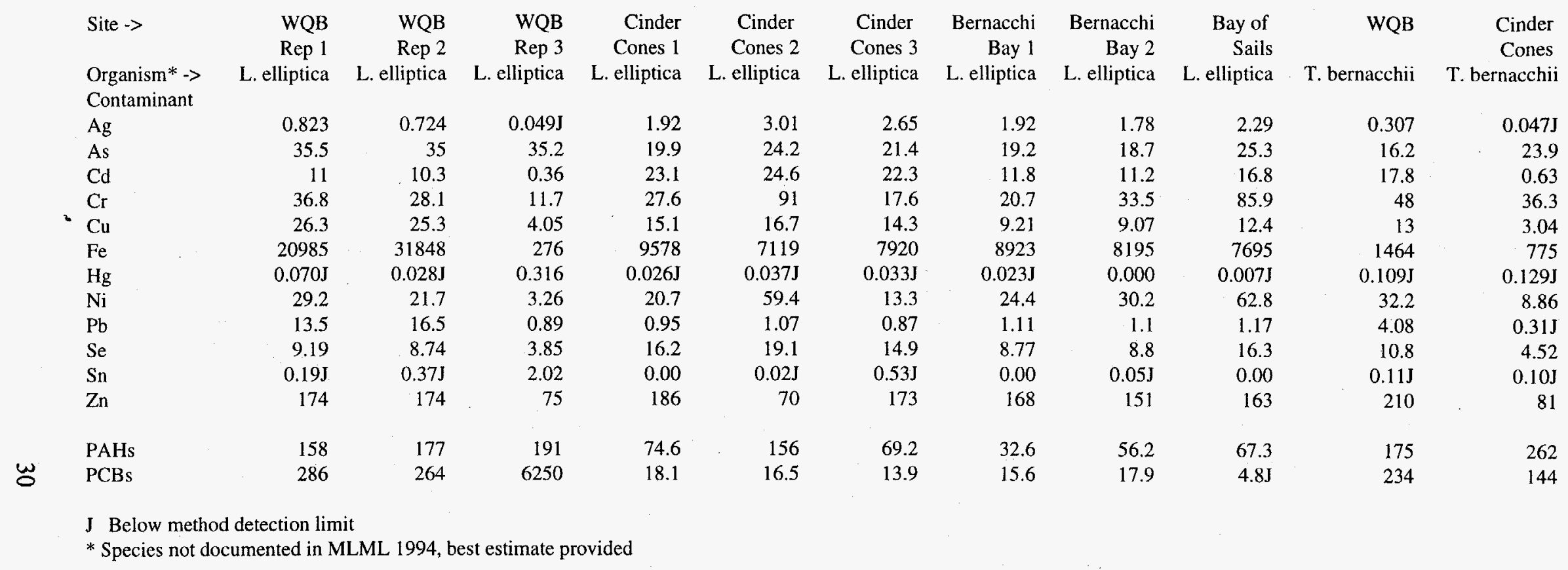


shows the available ERL and ERM as well as the frequency at which sediment samples exceed each criterion. For metals, the only ERM criterion routinely exceeded is for nickel. However, the background level of nickel in the area is high, and reference site levels are similar to levels in the bay. Two sediment samples exceeded the ERM criterion for $\mathrm{Cd}$, and one sample exceeded the ERM for $\mathrm{Hg}$. These data do not imply that metals are the source of adverse impacts on benthic biota.

For PCBs in Winter Quarters Bay sediments, all samples exceeded the ERL, and 78\% exceeded the ERM. For total PAHs, only $12 \%$ of the samples exceeded the ERL; and no samples exceeded the ERM. For high molecular weight PAHs, no bay sediment samples exceeded the ERL, but for low molecular weight PAHs, $88 \%$ of the samples exceeded the ERL and 19\% exceeded the ERM. Obviously, the low molecular weight PAHs are more likely to cause toxic impacts than the higher weight PAHs. For individual PAHs, only 2-methyl naphthalene and fluorene exceeded the ERL, and no single PAH exceeded an ERM (Table 4).

In summary, based on comparisons of contaminants levels in Winter Quarters Bay and comparisons to ERM and ERL criteria, PCBs appear to be the most likely contaminant linked to toxic effects in the bay. However, according to Long et al. (1995), the incidence of adverse effects is only low when sediment PCB levels are in the probable effects range (levels exceed the ERM).

Other possible sources of adverse impacts are other petroleum hydrocarbons that were measured in bay sediments such as TPH (both jet and diesel) and purgeable hydrocarbons (Table 2). No ERL or ERM criteria exist for these groups of compounds. High levels of purgeable organics, up to 4,500 ppm, were reported by Lenihan et al. (1990), and other data on the same samples showed high levels of TPH, both jet and diesel. More detailed data were obtained from Lenihan et al. (1990) on the levels of VOCs and semivolatile organics in sediments from two locations in the bay (MLML 1994). Duplicate samples from a depth of $33 \mathrm{~m}$ were reported as well as a sample from $24 \mathrm{~m}$. Both samples were collected from the back bay section of Winter Quarters Bay, which contains the most contaminated sediments. The samples were collected during 1988 and analyzed by Central Coast Analytical Services using U.S. Environmental Protection Agency (EPA) Methods 5030/8240 (purge and trap/GC-MS) for VOCs and 8270 (GC-MS) for semivolatile organics and pesticides and PCBs. No target toxic organic compound was detected at the practical quantitation limits of 5 to $100 \mu \mathrm{g} / \mathrm{kg}$ for VOCs, 100 to $10,000 \mu \mathrm{g} / \mathrm{kg}$ for semivolatiles, and 100 to $5,000 \mu \mathrm{g} / \mathrm{kg}$ for pesticides. The one sediment sample analyzed for total purgeable petroleum hydrocarbons from the $33-\mathrm{m}$ site was reported to contain $400,000 \mu \mathrm{g} / \mathrm{kg}$. From the semivolatile organic samples, TPH levels were reported as $150,000 \mu \mathrm{g} / \mathrm{kg}$ TPH (jet) and $10.000 \mu \mathrm{g} / \mathrm{kg}$ TPH (No. 4 diesel) for the $33-\mathrm{m}$ site. For the $24-\mathrm{m}$ site, the comparable levels were $500,000 \mu \mathrm{g} / \mathrm{kg} \mathrm{TPH}$ (jet) and $90,000 \mu \mathrm{g} / \mathrm{kg}$ TPH (No. 4 diesel). These results are consistent with the presence of degraded fuels or oil in which large quantities of aliphatic hydrocarbons are present but the more easily degraded aromatics such as benzene, toluene, xylene, and ethyl benzene have been lost or are masked by other hydrocarbons in the sample. Risebrough ${ }^{e}$ noted that the substrate at Winter Quarters Bay is not really sediment but "goo."

e. Personal communication. 
Table 4. Summary of selected PAHs (ng/g) in Winter Quarters Bay sediments (MLML 1994).

Location >

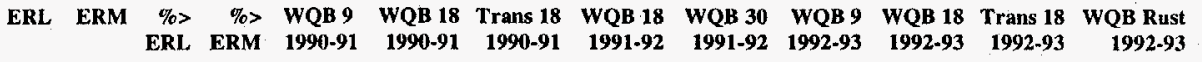

WQB B. R. WQB

$\begin{array}{rrrrrr}\text { QB B.C. } & \text { IceDock18 } & \text { WQB B. V. } & \text { WQB 33 } & \text { WQB B.S. } & \text { Dock } 18 \\ 1992-93 & 1992-93 & 1992-93 & 1992-93 & 1992.93 & 1992-93\end{array}$

2-Methylnaphthalene Acenaphthene Acenaphthyle

Anthracene

Ben(a)anthracene

Benzo(a)pyrene

Chrysene

Dibenzo(a,h)anthracene

Fluoranthene

70) 670

1992-93 1992-93

Naphthalene

Phenanthrane

Pyrene

\begin{tabular}{rr|}
16 & 500 \\
44 & 640 \\
85.3 & 1100 \\
\hline & 1600
\end{tabular}

$\begin{array}{rr}85.3 & 1100 \\ 261 & 1600\end{array}$ $\begin{array}{ll}430 & 1600\end{array}$ $\begin{array}{rr}384 & 2800 \\ 63.4 & 260\end{array}$ $\begin{array}{rr}600 & 5100 \\ 19 & 540\end{array}$ \begin{tabular}{rr|}
19 & 540 \\
160 & 2100
\end{tabular} $\begin{array}{ll}160 & 2100 \\ 240 & 1500\end{array}$ $240 \quad 1500$

Low Mol. Wt. PAHs High Mol. Wt. PAHs Total PAH's

\begin{tabular}{rr}
322 & 157 \\
11 & 5 \\
5 & 3 \\
56 & 12 \\
18 & 21 \\
8 & 9 \\
46 & 27 \\
1 & 1 \\
47 & 31 \\
48 & 11 \\
137 & 68 \\
94 & 44 \\
65 & 45 \\
& \\
& 1868 \\
819 & 449 \\
\hline 67 & 2317
\end{tabular}

1
1
3
4
4
6
1
8
3
19
13
14
390
162

$\begin{array}{rrrrr}28 & 255 & 116 & 203 & 80 \\ 1 & 13 & 3 & 6 & 2 \\ 1 & 5 & 2 & 4 & 1 \\ 3 & 19 & 6 & 15 & 34 \\ 2 & 37 & 19 & 35 & 13 \\ 1 & 20 & 11 & 23 & 8 \\ 3 & 49 & 20 & 41 & 47 \\ 0 & 3 & 2 & 3 & 2 \\ 9 & 86 & 33 & 99 & 21 \\ 3 & 19 & 7 & 13 & 9 \\ 14 & 99 & 65 & 95 & 40 \\ 12 & 94 & 24 & 64 & 26 \\ 12 & 90 & 42 & 92 & 20 \\ 545 & 2645 & 1003 & 1558 & 570 \\ \mathbf{5 4 2} & \mathbf{7 4 2} & \mathbf{4 0 7} & \mathbf{8 2 8} & 293 \\ \mathbf{6 8 7} & \mathbf{3 3 8 7} & 1410 & \mathbf{2 3 8 6} & \mathbf{8 6 3}\end{array}$

136
4
1
6
12
8
17
1
29
7
56
20
36
857
290
1147

$\begin{array}{rr}426 & 33 \\ 19 & 1 \\ 2 & 1 \\ 8 & 2 \\ 15 & 4 \\ 10 & 5 \\ 28 & 6 \\ 2 & 1 \\ 610 & 9 \\ 27 & 2 \\ 145 & 15 \\ 73 & 6 \\ 56 & 9 \\ 2298 & 213 \\ 495 & 99 \\ 2793 & 312\end{array}$

$\begin{array}{rrr}352 & 493 \\ 16 & \\ 1 & \\ 8 & \\ 15 & \\ 9 & \\ 19 & \\ 1 & \\ 46 & \\ 25 & \\ 101 & 118 \\ 54 & \\ 48 & \\ & \\ 2694 & 5 \\ 404 & 858 \\ 3098 & 6339\end{array}$

$\begin{array}{rr}203 & 71 \\ 4 & 3 \\ 4 & 1 \\ 13 & 6 \\ 21 & 13 \\ 18 & 9 \\ 41 & 17 \\ 3 & 1 \\ 53 & 42 \\ 11 & 8 \\ 1102 & 28 \\ 39 & 27 \\ 60 & 44 \\ 1376 & 1594 \\ 710 & 319 \\ 7086 & 1913\end{array}$




\subsection{Idaho National Engineering and Environmental Laboratory Data}

Personnel from the INEEL collected sediment samples using an Ekman dredge in December 1993 on a 50-by-50-m systematic grid covering Winter Quarters Bay (Figure 1). Sampling location coordinates and water depths are presented in Appendix A. Depth measurements were made during sampling using a weighted line, and a bathymetric chart of the bay was subsequently developed. Thirty eight sediment samples were screened for PCBs and toxicity using Microtox, and ASA personnel stationed at McMurdo screened nine samples for VOCs. In addition, a set of 39 sediment samples (38 from the bay; and sample 0000 was a reference sample collected near the drinking water intake) was sent to the Geochemical Environmental Research Group (GERG), which analyzed the nine samples (as well as the control sample) for NOAA National Status and Trends organics (NOAA 1993). No data on the vertical extent of contamination were obtained. Sediment cores could not be collected because of the gravel-size coarse particles mixed with the silt and clay. The analytical data are summarized in Table 5.

The ASA screening quantitation level for PCBs was $500 \mathrm{ppb}$ on a wet weight basis. Seven of the 38 samples exceeded that level, while the maximum was $1,600 \mathrm{ppb}$ (Figure 7) or 2,600 ppb on a dry weight basis. The ASA results correlate reasonably well with split samples analyzed by GERG. Nine sediment samples were screened for VOCs using purge-and-trap analytical procedures, and six contained detectable concentrations at low levels. Total xylenes ranged from 11 to $140 \mathrm{ppb}$, while ethyl benzene, 1,4 dichlorobenzene, and toluene each was detected once at levels of 28,16 , and $11 \mathrm{ppb}$, respectively. The ASA Microtox screening results showed that only one (L-125) of 21 sediment pore water samples was toxic, using EC50 as the endpoint. The results are somewhat questionable, however, because supernatant water above the sample was analyzed instead of supernatant water from the centrifugation of the samples, as specified.

GERG also determined percent moisture, total organic carbon, silt, and clay. The data are presented in Table 5, the distribution of organic carbon is shown in Figure 4, and the distributions of silt and clay are shown in Figure 3.

The PCB results determined by GERG for nine bay sediment samples analyzed by NOAA national status and trends methods show levels ranging from 250 to $4,300 \mathrm{ppb}$ (Table 5). Because the toxicity of organic compounds in sediments usually is strongly related to the organic carbon content of sediments, data often are normalized to $1 \%$ organic carbon. For the same contaminant concentration, as the organic carbon content of a sediment increases, toxicity decreases. Figure 7 shows the sampling location and analytical results from both the ASA and GERG normalized to $1 \%$ organic carbon. Because most of the bay sediment samples contain less than 1\% organic carbon, PCB concentrations in Figure 7 are higher than those in Table 5. All of the bay samples analyzed by GERG exceeded the ERM for PCBs.

Total PAH levels for the same nine samples ranged from 364 to $12,848 \mathrm{ppb}$. The analytical results are presented in Table 6 , the same data normalized to $1 \%$ carbon are shown in Table 7 , and the same total PAH data normalized to $1 \%$ organic carbon are shown in Figure 8. Only one of the nine samples exceeded the ERL for total PAH, and even the highest level is about an order of magnitude below the ERM. Closer examination of the data shows that while most individual PAHs are well below their respective ERL, seven of nine samples exceeded the ERL for 2-methylnaphthalene, and eight of nine samples exceeded the ERL for low molecular weight PAHs. Both tables show the PAHs determined by GERG, and show the ERL, ERM, 


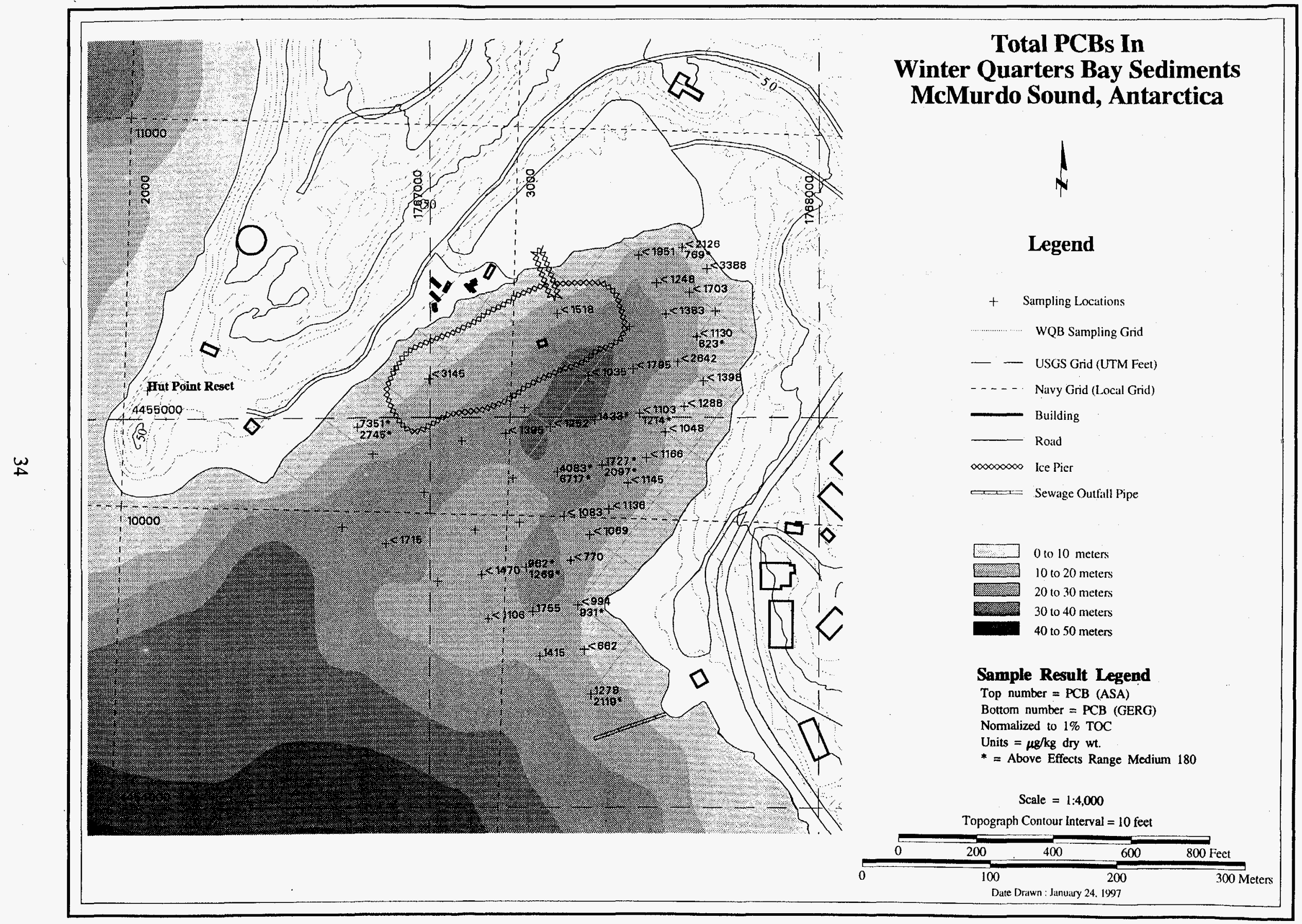

Figure 7. Total PCBs in Winter Quarters Bay sediments, McMurdo Sound, Antarctica. 


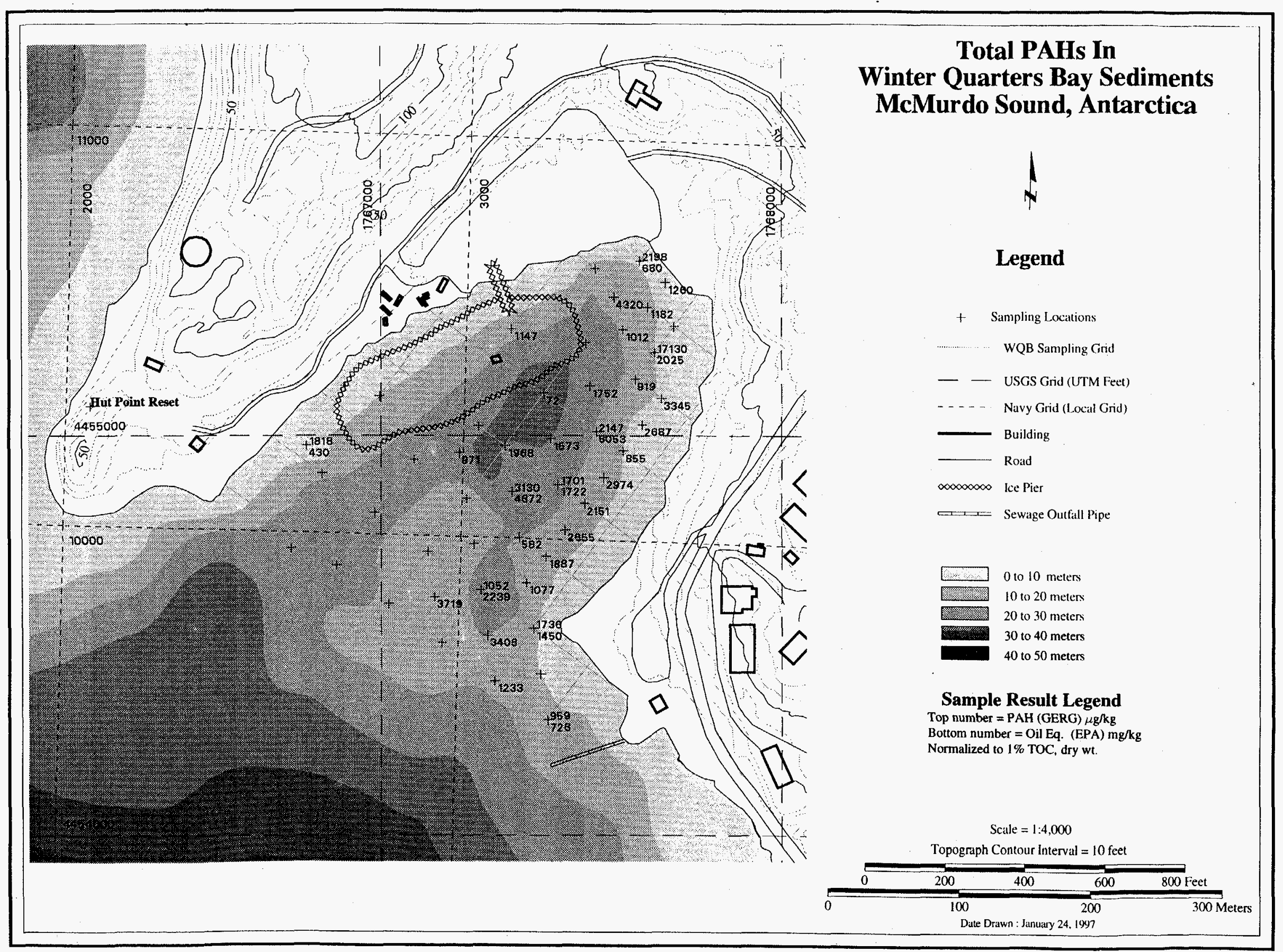

Figure 8. Total PAHs and oil-eq. in Winter Quarters Bay sediments, McMurdo Sound, Antarctica. 
Table 5. Summary of INEEL analytical data on Winter Quarters Bay sediments.

\begin{tabular}{|c|c|c|c|c|c|c|c|c|c|c|c|c|c|}
\hline & Moist & TOC & Silt & Clay & $\begin{array}{l}\text { DMSO-TJ } \\
\text { Toxicity }\end{array}$ & $\begin{array}{r}\text { DMSO-M } \\
\text { Toxicity }\end{array}$ & $\begin{array}{l}\text { Whole Sed. } \\
\text { Toxicity }\end{array}$ & $\begin{array}{r}\text { PCBs } \\
\text { ASA }\end{array}$ & $\begin{array}{l}\text { PCBs } \\
\text { GERG }\end{array}$ & $\begin{array}{r}\text { Oil-Eq } \\
\text { EPA }\end{array}$ & $\begin{array}{l}\text { PAHs } \\
\text { GERG }\end{array}$ & $\begin{array}{r}\text { L PAHs } \\
\text { GERG }\end{array}$ & $\begin{array}{r}\text { M/naph } \\
\text { GERG }\end{array}$ \\
\hline $\begin{array}{l}\text { Units > } \\
\text { Site }\end{array}$ & $\%$ & $\%$ & $\%$ & $\%$ & EC 50 & LOEC $(\%)$ & $\operatorname{LOEC}(\%)$ & $\mathrm{ng} / \mathrm{g}$ & $\mathrm{ng} / \mathrm{g}$ & ug/g & $\mathrm{ng} / \mathrm{g}$ & $\mathrm{ng} / \mathrm{g}$ & $\mathrm{ng} / \mathrm{g}$ \\
\hline A- -25 & 49.3 & 0.9 & 17.9 & 22.3 & 1.20 & 0.125 & 0.020 & 1124 & 1865 & 639 & 844 & 646 & 128 \\
\hline A-75 & 44.0 & 1.1 & 3.6 & 8.6 & 0.79 & 0.063 & 0.040 & 1500 & na & 1307 & na & na & na \\
\hline A- 125 & 20.8 & 0.6 & 24.2 & 15.5 & na & na & na & nd & na & na & na & na & na \\
\hline A- 225 & 16.7 & 0.4 & 0.4 & 8.8 & na & na & na & nd & na & na & na & na & na \\
\hline B-50 & 42.8 & 1.3 & 19.7 & 16.4 & 0.32 & 0.016 & 0.016 & nd & na & 2212 & na & na & na \\
\hline B-100 & 45.0 & 0.9 & 22.6 & 16.6 & 0.27 & 0.008 & 0.020 & 1527 & na & 2964 & na & na & na \\
\hline B-150 & 20.9 & 0.4 & 1.3 & 5.5 & na & na & na & na & na & na & na & na & na \\
\hline C-75 & 42.2 & 0.9 & 26.8 & 18.1 & 1.00 & 0.016 & 0.020 & nd & 810 & 1261 & 1510 & 1030 & 123 \\
\hline C- 125 & 42.5 & 1.4 & 15.3 & 16.5 & 0.57 & 0.031 & 0.080 & 1357 & 1789 & 3157 & 1483 & 897 & 117 \\
\hline C-298 & 27.9 & 0.2 & 30.9 & 25.8 & 0.79 & 0.063 & 0.020 & 1470 & 549 & 86 & 364 & 280 & 57 \\
\hline D- 100 & 46.3 & 1.2 & 30.8 & 16.3 & 0.16 & 0.063 & 0.040 & nd & na & 1304 & na & na & na \\
\hline E-100 & 43.7 & 0.8 & 31.0 & 12.6 & 0.45 & 0.063 & 0.040 & nd & na & 1567 & na & na & na \\
\hline E-125 & 49.8 & 0.9 & 34.7 & 16.6 & 0.54 & 0.024 & 0.040 & nd & na & 536 & na & na & na \\
\hline$F-100$ & 45.0 & 0.8 & 31.0 & 18.8 & 0.58 & 0.016 & 0.020 & nd & na & 2124 & na & na & na \\
\hline F- 150 & 40.3 & 0.6 & 21.8 & 12.2 & 0.74 & 0.125 & 0.310 & 2613 & 4299 & 2990 & 2003 & 1398 & 147 \\
\hline F-200 & 37.1 & 0.6 & 20.8 & 9.4 & 0.81 & 0.031 & 0.020 & nd & na & 553 & na & na & na \\
\hline F-275 & 20.5 & 0.2 & 3.2 & 3.5 & na & na & na & nd & na & na & na & na & na \\
\hline F-310 & 27.1 & 0.1 & 0.3 & 6.7 & na & na & na & nd & na & na & na & na & na \\
\hline G-100 & 43.3 & 0.8 & 41.3 & 13.3 & 0.81 & 0.031 & 0.310 & nd & na & 1656 & na & na & na \\
\hline G-125 & 44.6 & 1.2 & 23.5 & 20.0 & 0.59 & 0.063 & 0.016 & 1986 & 2411 & 1980 & 1957 & 1423 & 114 \\
\hline G-175 & 40.4 & 0.7 & 44.3 & 12.4 & 0.69 & 0.031 & 0.004 & nd & na & 1319 & na & na & na \\
\hline $\mathrm{H}-100$ & 45.0 & 0.8 & 42.2 & 19.2 & 0.53 & 0.031 & 0.004 & nd & na & 2320 & na & na & na \\
\hline H-150 & 44.6 & 0.6 & 49.4 & 15.0 & 0.52 & 0.016 & 0.004 & nd & na & 991 & na & na & na \\
\hline I- 100 & 47.0 & 0.9 & 51.9 & 20.8 & 0.54 & 0.016 & 0.040 & nd & na & 770 & na & na & na \\
\hline I- 125 & 45.4 & 0.8 & 34.5 & 14.9 & 0.25 & 0.031 & 0.040 & nd & 1008 & 5024 & 1782 & 1316 & 54 \\
\hline I-175 & 19.5 & 0.6 & 1.1 & 2.7 & 0.70 & 0.125 & 0.310 & nd & na & 43 & na & na & na \\
\hline$J-100$ & 39.3 & 0.6 & 48.2 & 27.4 & 0.16 & 0.016 & 0.020 & nd & na & 1720 & na & na & na \\
\hline J-150 & 52.8 & 0.6 & 40.2 & 18.4 & 0.53 & 0.031 & 0.040 & nd & na & 1034 & na & na & na \\
\hline $\mathrm{J}-225$ & 29.9 & 0.5 & 14.9 & 5.5 & 0.92 & 0.500 & 0.310 & nd & na & 539 & na & na & na \\
\hline$K-100$ & 39.4 & 0.6 & 58.1 & 25.4 & 0.33 & 0.063 & 0.020 & nd & na & 1974 & na & na & na \\
\hline $\mathrm{K}-125$ & 29.9 & 0.3 & 13.8 & 4.3 & 0.81 & 0.250 & 0.310 & nd & na & 248 & na & na & na \\
\hline L-125 & 41.0 & 0.8 & 28.1 & 11.0 & 0.39 & 0.063 & 0.040 & nd & 617 & 1519 & 12848 & 12319 & 363 \\
\hline L-155 & 42.6 & 0.6 & 41.4 & 11.3 & 0.58 & 0.063 & 0.040 & nd & na & 638 & na & na & na \\
\hline M-150 & 24.7 & 0.4 & 9.1 & 6.0 & 0.98 & 0.250 & 0.080 & nd & na & 461 & na & na & na \\
\hline M-175 & 46.6 & 0.8 & 45.8 & 20.6 & 0.31 & 0.016 & 0.020 & nd & na & 3240 & na & na & na \\
\hline$M-200$ & 35.9 & 0.4 & 11.5 & 8.1 & na & na & na & nd & na & na & na & na & na \\
\hline $\mathrm{N}-150$ & 26.3 & 0.2 & 18.4 & 6.1 & 0.60 & 0.063 & 0.080 & nd & na & 252 & na & na & na \\
\hline $\mathrm{N}-175$ & 26.5 & 0.3 & 9.9 & 4.0 & 1.60 & 0.500 & 0.040 & nd & 246 & 218 & 703 & 566 & 82 \\
\hline 0000 & 39.8 & 0.6 & 27.6 & 8.5 & 1.10 & 0.500 & 0.080 & nd & 64 & 13 & 76 & 44 & 6 \\
\hline
\end{tabular}

DMSO-TJ, Microtox bioassay on sediment extracts by Tom Johnson, Midwest Science Center DMSO-M, Microtox chronic bioassay on sediment extracts, data from Microbics Corp.

Whole Sed. $=$ Chronic Microtox data on whole sediments by Microbics Corp.

All chemical analyses on a dry weight basis

Oil-Eq $=$ SAE 30 motor oil equivalent

$\mathrm{nd}=$ not detected at detection limit of $-500 \mathrm{ng} / \mathrm{g}$, wet weight.

na $=$ not analyzed 
Table 6. PCBs and PAHs in Winter Quarters Bay sediments.

\begin{tabular}{|c|c|c|c|c|c|c|c|c|c|c|c|c|c|c|}
\hline $\begin{array}{l}\text { Sample Location } \\
\text { Lab Sample No. C13 } \\
\text { Units: }\end{array}$ & $\begin{array}{l}\text { Effects } \\
\text { Range } \\
\text { Lowt }\end{array}$ & $\begin{array}{l}\text { Effects } \\
\text { Range } \\
\text { High+ }\end{array}$ & $\begin{array}{r}\text { Marine* } \\
\text { Sediment } \\
\text { Criteria }\end{array}$ & $\begin{array}{r}\text { Maximum } \\
\text { Detected } \\
\text { Level }\end{array}$ & $\begin{array}{r}\text { A.25 } \\
264 \\
n g / g\end{array}$ & $\begin{array}{r}\text { C.75 } \\
271 \\
\mathrm{ng} / \mathrm{g}\end{array}$ & $\begin{array}{r}\mathrm{C} \cdot 125 \\
272 \\
\mathrm{ng} / \mathrm{g}\end{array}$ & $\begin{array}{r}\mathrm{C}-298 \\
273 \\
\mathrm{ng} / \mathrm{g}\end{array}$ & $\begin{array}{r}\text { F-150 } \\
278 \\
\text { ng/g }\end{array}$ & $\begin{array}{r}\text { G-125 } \\
283 \\
n g / g\end{array}$ & $\begin{array}{r}\mathbf{I} \cdot 125 \\
288 \\
\mathrm{ng} / \mathrm{g}\end{array}$ & $\begin{array}{r}\mathrm{L}-125 \\
295 \\
\mathrm{ng} / \mathrm{g}\end{array}$ & $\begin{array}{r}N-175 \\
301 \\
n g / g\end{array}$ & $\begin{array}{r}0060 \\
302 \\
n g / g\end{array}$ \\
\hline Total PCBs & 22.7 & 180 & 120 & 4299 & 1865 & 810 & 1789 & 549 & 4299 & 2411 & 1008 & 617 & 246 & 64 \\
\hline Naphthalene & 160 & 2100 & 990 & 97 & 80.1 & 80.8 & 67.2 & 40.2 & $96.6 \$$ & 61.3 & $33.2 \mathrm{M}$ & 86.3 & 19.2 & $4.6 \mathrm{~J}$ \\
\hline C1-Naphthalenes & & & & 528 & 177.1 & 171.1 & 157.4 & 76.2 & $200.5 \$$ & 158.9 & $76.0 \mathrm{M}$ & $\mathbf{5 2 7 . 6}$ & 142.3 & $8.0 \mathrm{~J}$ \\
\hline C2-Naphthalenes & & & & 9639 & 112.0 & 135.1 & 105.5 & 41.9 & $113.9 \$$ & 130.6 & $134.8 \mathrm{M}$ & 9639 & 122.6 & $7.2 \mathrm{~J}$ \\
\hline C3-Naphthatenes & & & & 1090 & 48.5 & 93.4 & 71.3 & 22.7 & $175.4 \$$ & 149.6 & $357.4 \mathrm{M}$ & 1090 & 108.4 & $7.0 \mathrm{~J}$ \\
\hline C4-Naphthalenes & & & & 334 & 24.7 & 52.3 & 45.3 & $7.9 \mathrm{~J}$ & $174.7 \$$ & 126.8 & $228.7 \mathrm{M}$ & 333,6 & 54.6 & nd \\
\hline Biphenyl & & & & 39 & 19.6 & 30.2 & 31.7 & 12.2 & $19.9 \$$ & 25.8 & $10.1 \mathrm{M}$ & 38.7 & $7.3 \mathrm{~J}$ & $1.6 \mathrm{~J}$ \\
\hline Acenaphthylene & 44 & 640 & 660 & & $3.3 \mathrm{~J}$ & $4.1 \mathrm{~J}$ & $3.6 \mathrm{~J}$ & $0.5 \mathrm{~J}$ & $2.9 \$ \mathrm{~J}$ & $3.4 \mathrm{~J}$ & $1.8 \mathrm{M}$ & $2,4 \mathrm{~J}$ & $0.6 \mathrm{~J}$ & $0.3 \mathrm{~J}$ \\
\hline Acenaphthene & 16 & 500 & 160 & 15 & $1.7 \mathrm{~J}$ & $5.2 \mathrm{~J}$ & $3.2 \mathrm{~J}$ & $1.5 \mathrm{~J}$ & $7.8 \$ \mathrm{~J}$ & $7.0 \mathrm{~J}$ & $3.2 \mathrm{M}$ & 15.2 & $2.5 \mathrm{~J}$ & $0.3 \mathrm{~J}$ \\
\hline Fluorene & 19 & 540 & 230 & 20 & $5.8 \mathrm{~J}$ & 11.4 & $8.2 \mathrm{~J}$ & $1.5 \mathrm{~J}$ & $8.9 \$$ & 9.2 & $7.6 \mathrm{M}$ & 20.0 & $4.4 \mathrm{~J}$ & $0.5 \mathrm{~J}$ \\
\hline C1-Fluorenes & & & & 30 & $7.1 \mathrm{~J}$ & $14.1 \mathrm{~J}$ & $13.4 \mathrm{~J}$ & $2.6 \mathrm{~J}$ & $22.8 \$$ & 23.3 & $19,9 \mathrm{M}$ & 30.5 & $5.5 \mathrm{~J}$ & nd \\
\hline C2-Fluorenes & & & & 71 & $10.7 \mathrm{~J}$ & 30.6 & 32.4 & $3.7 \mathrm{~J}$ & $70.8 \$$ & 60.6 & $61.8 \mathrm{M}$ & 60.7 & $9.6 \mathrm{~J}$ & nd \\
\hline C3-Fluorenes & & & & 97 & 18.9 & 49.7 & 51.1 & $9.2 \mathrm{~J}$ & $97.2 \$$ & 73,1 & $78.5 \mathrm{M}$ & 76.2 & 13.2 & nd \\
\hline Phenanthrene & 240 & 1500 & 1,000 & 56 & 20.9 & 49.7 & 40.2 & $7.1 \mathrm{~J}$ & 33.9 & 33.9 & $31.4 \mathrm{M}$ & 56.3 & 15.8 & $1.6 \mathrm{~J}$ \\
\hline Anthracene & 85.3 & 1100 & 2,200 & 12 & $4.0 \mathrm{~J}$ & 11.4 & 9.2 & $3.3 \mathrm{~J}$ & 12.2 & 9.3 & $9.0 \mathrm{M}$ & 10.5 & $3.1 \mathrm{~J}$ & $0.3 \mathrm{~J}$ \\
\hline C1-Phenanthrene & & & & 300 & $13.7 \mathrm{~J}$ & 35.8 & 24.1 & $4.9 \mathrm{~J}$ & 39.4 & 299.6 & $33.8 \mathrm{M}$ & 59.1 & $6.8 \mathrm{~J}$ & $1.8 \mathrm{~J}$ \\
\hline C2-Phenanthrere & & & & 101 & $21.1 \mathrm{~J}$ & 66.5 & 52.4 & $8.3 \mathrm{~J}$ & 83.0 & 63.6 & $70.2 \mathrm{M}$ & 101.2 & $14.5 \mathrm{~J}$ & $3.3 \mathrm{~J}$ \\
\hline C3-Phenanthrene & & & & 169 & 43.4 & 103.3 & 103.2 & 23.3 & 168.6 & 128.3 & $108.1 \mathrm{M}$ & 106.0 & 19.4 & $3.7 \mathrm{~J}$ \\
\hline C4-Phenanthrene & & & & 86 & 33.0 & 86.0 & 77.6 & $13.1 \mathrm{~J}$ & 69.9 & 59.2 & $50.6 \mathrm{M}$ & 65.8 & $16.7 \mathrm{~J}$ & nd \\
\hline Dibenzothiophene & & & & 13 & $3.2 \mathrm{~J}$ & $7.1 \mathrm{~J}$ & $7.0 \mathrm{~J}$ & $2.3 \mathrm{~J}$ & 12.5 & $8.1 \mathrm{~J}$ & $9.9 \mathrm{M}$ & $11.6 \mathrm{~J}$ & $1.7 \mathrm{~J}$ & $0.3 \mathrm{~J}$ \\
\hline C1-Dibenzothiophene & & & . & 37 & $5.5 \mathrm{~J}$ & $18.3 \mathrm{~J}$ & $18.0 \mathrm{~J}$ & $2.4 \mathrm{~J}$ & $22.4 \mathrm{~J}$ & $24.6 \mathrm{~J}$ & $21.5 \mathrm{M}$ & 37.1 & $3.6 \mathrm{~J}$ & $0.8 \mathrm{~J}$ \\
\hline C2-Dibenzothiophene & & & & 112 & $22.1 \mathrm{~J}$ & 77.8 & 65.9 & $7.5 \mathrm{~J}$ & 111.5 & 97.7 & $88.8 \mathrm{M}$ & 102.8 & $12.2 \mathrm{~J}$ & $2.6 \mathrm{~J}$ \\
\hline C3-Dibenzothiophene & & & & 165 & $23.8 \mathrm{~J}$ & 102.1 & 118.3 & $12.3 \mathrm{~J}$ & 164.7 & 130.0 & $121.9 \mathrm{M}$ & 98.4 & $16.5 \mathrm{~J}$ & $4.5 \mathrm{~J}$ \\
\hline Fluoranthene & 600 & 5100 & 1,600 & 70 & 16.6 & 64.3 & 69.7 & 7.8 & $\mathbf{5 4 . 0}$ & 45.7 & $37.5 \mathrm{M}$ & 53.0 & 17.5 & $3.3 \mathrm{~J}$ \\
\hline Pyrene & 665 & 2600 & 10,090 & 61 & 20.8 & 57.0 & 58.5 & 8.1 & 60.8 & 51.7 & $43.9 \mathrm{M}$ & 55.8 & 22.1 & $3.2 \mathrm{~J}$ \\
\hline C1-Fuoranthene/Pyrene & & & & 63 & 14.7 & 37.8 & 44.3 & $7.3 \mathrm{~J}$ & 34.4 & 30.7 & $28.0 \mathrm{M}$ & 62.7 & 20.9 & $2.1 \mathrm{~J}$ \\
\hline Benz(a)anthracene & 261 & 1600 & 1,100 & 26 & 6.6 & 16.2 & 25.7 & 3.5 & 22.3 & 21.8 & $12.6 \mathrm{M}$ & 17.4 & 6.5 & $1.1 \mathrm{~J}$ \\
\hline Chrysene & 384 & 2800 & 1,100 & 38 & 15.3 & 18.9 & 37.6 & $7.0 \mathrm{~J}$ & 18.2 & 22.3 & 23.1 & 17.2 & $7.5 \mathrm{~J}$ & $2.0 \mathrm{~J}$ \\
\hline C1-Chrysenes & & & & 29 & $12.1 \mathrm{~J}$ & $19.0 \mathrm{~J}$ & 29.1 & $3.7 \mathbf{J}$ & 28.0 & $18.1 \mathrm{~J}$ & $22.7 \mathrm{~J}$ & $18.6 \mathrm{~J}$ & $6.0 \mathrm{~J}$ & $3.3 \mathrm{~J}$ \\
\hline C2-Chrysenes & & & & 26 & $7.9 \mathrm{~J}$ & $17.5 \mathrm{~J}$ & $24.9 \mathrm{~J}$ & $4.4 \mathrm{~J}$ & 25.9 & $18.7 \mathrm{~J}$ & $17.9 \mathrm{~J}$ & $15.5 \mathrm{~J}$ & $4.7 \mathrm{~J}$ & $3.2 \mathrm{~J}$ \\
\hline C3-Chrysenes & & & & & $3.7 \mathrm{~J}$ & $5.6 \mathrm{~J}$ & $6.0 \mathrm{~J}$ & $0.9 \mathrm{~J}$ & $2.5 \mathrm{~J}$ & $2.3 \mathrm{~J}$ & $1.3 \mathrm{~J}$ & $3.8 \mathrm{~J}$ & $1.3 \mathrm{~J}$ & nd \\
\hline C4-Chrysenes & & & & & $7.2 \mathrm{~J}$ & nd & $3.0 \mathrm{~J}$ & $0.7 \mathrm{~J}$ & $2.5 \mathrm{~J}$ & $1.4 \mathrm{~J}$ & $1.3 \mathrm{~J}$ & $1.9 \mathrm{~J}$ & $1.4 \mathrm{~J}$ & nd \\
\hline Benzo(b)fluoranthene & & & & 16 & $6.5 \mathrm{~J}$ & $7.2 \mathrm{~J}$ & 15.6 & $2.6 \mathrm{~J}$ & $8.2 \mathrm{~J}$ & $10.6 \mathrm{~J}$ & $6.5 \mathrm{~J}$ & $8.2 \mathrm{~J}$ & $3.2 \mathrm{~J}$ & $1.3 \mathrm{~J}$ \\
\hline Benzo(k)fluoranthene & & & & 15 & $6.4 \mathrm{~J}$ & $6.7 \mathrm{~J}$ & 15.4 & $2.6 \mathrm{~J}$ & $8.1 \mathrm{~J}$ & $10.5 \mathrm{~J}$ & $6.4 \mathrm{~J}$ & $6.4 \mathrm{~J}$ & $3.1 \mathrm{~J}$ & $1.3 \mathrm{~J}$ \\
\hline Benzo(e)pyrene & & & & 14 & 7.7 & 8.0 & 14.3 & $2.9 \mathrm{~J}$ & 8.9 & 10.9 & 6.7 & 7.0 & $3.3 \mathrm{~J}$ & $1.9 \mathrm{~J}$ \\
\hline Benzo(a)pyrene & 430 & 1600 & 990 & 11 & $5.7 \mathrm{~J}$ & $6.2 \mathrm{~J}$ & 11.2 & $2.4 \mathrm{~J}$ & $7.3 \mathrm{~J}$ & $10.5 \mathrm{~J}$ & $6.1 \mathrm{~J}$ & $3.9 \mathrm{~J}$ & $1.9 \mathrm{~J}$ & $1.2 \mathrm{~J}$ \\
\hline Perylene & & & & & $2.1 \mathrm{~J}$ & $2.4 \mathrm{~J}$ & $4.3 \mathrm{~J}$ & $0.8 \mathrm{~J}$ & $4.1 \mathrm{~J}$ & $4.9 \mathrm{~J}$ & $2.9 \mathrm{~J}$ & $1.2 \mathrm{~J}$ & $0.9 \mathrm{~J}$ & $0.7 \mathrm{sJ}$ \\
\hline Indeno(1,2,3-cd)pyrene & & & 340 & 9 & $4.6 \mathrm{~J}$ & $3.5 \mathrm{~J}$ & 8.9 & $1.8 \mathrm{~J}$ & $4.4 \mathrm{~J}$ & 6.7 & $3.6 \mathrm{~J}$ & $2.6 \mathrm{~J}$ & $1.5 \mathrm{~J}$ & $1.0 \mathrm{~J}$ \\
\hline Dibenzofah)anthracene & 63.4 & 260 & 120 & & $1.4 \mathrm{~J}$ & $1.1 \mathrm{~J}$ & $2.8 \mathrm{~J}$ & $0.7 \mathrm{~J}$ & $1.4 \mathrm{~J}$ & $2.7 \mathrm{~J}$ & $1.4 \mathrm{~J}$ & $1.1 \mathrm{~J}$ & $0.6 \mathrm{~J}$ & $0.3 \mathrm{~J}$ \\
\hline Benz(ghi)perylene & & & 310 & 10 & 7.0 & 5.2 & 10.2 & $2.7 \mathrm{~J}$ & 7.0 & 8.4 & 5.2 & $3.9 \mathrm{~J}$ & $2.2 \mathrm{~J}$ & $2.5 \mathrm{~J}$ \\
\hline $\begin{array}{l}\text { Total PAHs } \\
\text { (w/o Perylene) }\end{array}$ & 4022 & 44792 & & 12848 & 844 & 1510 & 1483 & 364 & 2003 & $1957 \mathrm{~J}$ & $1782 M$ & 12848 & 703 & $76 \mathrm{~J}$ \\
\hline Low Mol WL. PAHs & 552 & 3160 & 3700 & 12319 & 646 & 1030 & 897 & 280 & 1398 & 1423 & 1316 & 12319 & 566 & 40 \\
\hline High Mol Wt. PAHs & 1700 & 9600 & 9600 & 609 & 201 & 482 & 590 & 84 & 609 & 538 & 469 & 530 & 138 & 37 \\
\hline \multicolumn{15}{|l|}{ Specific PAHs } \\
\hline 2-Methylnaphthalene & 70 & 670 & 380 & 363 & 127.6 & 122.9 & 117.3 & 57.4 & $147.2 \$$ & 114.3 & $54.0 \mathrm{M}$ & 363.4 & 81.8 & $5.4 \mathrm{~J}$ \\
\hline 1-Methylnaphthalene & & & & 164 & 49.5 & 48.2 & 40.1 & $\mathbf{1 8 . 8}$ & $53.4 \$$ & 44.6 & $22.0 \mathrm{M}$ & 164.3 & 60.5 & $2.6 \mathrm{~J}$ \\
\hline 2,6-Dimethyinaphthalene & & & & 475 & 66.5 & 118.5 & 93.4 & 22.7 & $93.7 \$$ & 116.4 & $84.1 \mathrm{M}$ & 474.8 & 57.5 & $3.1 \mathrm{~J}$ \\
\hline 2,3,5-Trimethylnaphthalene & & & & 204 & 10.8 & 28.9 & 18.1 & $4.5 \mathrm{~J}$ & $46.3 \$$ & 41.9 & $64.1 \mathrm{M}$ & 203.9 & 24.1 & $0.5 \mathrm{~J}$ \\
\hline 1-Methylphenanthrene & & & & 15 & $3.1 \mathrm{~J}$ & $11.0 \mathrm{~J}$ & $7.6 \mathrm{~J}$ & $1.1 \mathrm{~J}$ & 13.1 & $8.7 \mathrm{~J}$ & $11.1 \mathrm{M}$ & 15.4 & $2.0 \mathrm{~J}$ & $0.3 \mathrm{~J}$ \\
\hline
\end{tabular}

$\mathbf{M}=$ Interferences with secondary ion

$\$$ = Analyte quantified from secondary ion

$\mathbf{J}=$ Concentration below method detection limit

* = Washington State Marine Sediment Criteria Adjusted to 1\% organic carbon (WDOE 1991)

$+=$ Long et al. 1995 
Table 7. PCBs and PAHs in Winter Quarters Bay sediments normalized to $1 \%$ organic carbon.

\begin{tabular}{|c|c|c|c|c|c|c|c|c|c|c|c|c|c|c|}
\hline $\begin{array}{l}\text { Sample Location } \\
\text { Lab Sample No. C13 } \\
\text { Units: }\end{array}$ & $\begin{array}{l}\text { Effects } \\
\text { Range } \\
\text { Low4 }\end{array}$ & $\begin{array}{l}\text { Effects } \\
\text { Range } \\
\text { Hight }\end{array}$ & $\begin{array}{r}\text { Marine* } \\
\text { Sediment } \\
\text { Criteria }\end{array}$ & $\begin{array}{r}\text { Maximum } \\
\text { Detected } \\
\text { Level }\end{array}$ & $\begin{array}{r}A-25 \\
264 \\
n g / g\end{array}$ & $\begin{array}{r}\text { C.75 } \\
271 \\
\mathrm{ng} / \mathrm{g}\end{array}$ & $\begin{array}{r}\mathrm{C} \cdot 125 \\
272 \\
\mathrm{ng} / \mathrm{g}\end{array}$ & $\begin{array}{r}\text { C.298 } \\
273 \\
\mathrm{ng} / \mathrm{g}\end{array}$ & $\begin{array}{r}\mathrm{F}-150 \\
278 \\
\mathrm{ng} / \mathrm{g}\end{array}$ & $\begin{array}{r}\mathrm{G}-125 \\
283 \\
\mathrm{ng} / \mathrm{g}\end{array}$ & $\begin{array}{r}\text { I-125 } \\
288 \\
\mathrm{ng} / \mathrm{g}\end{array}$ & $\begin{array}{r}\text { L-125 } \\
295 \\
\mathrm{ng} / \mathrm{g}\end{array}$ & $\begin{array}{r}\text { N-175 } \\
301 \\
\text { ng/g }\end{array}$ & $\begin{array}{r}0000 \\
302 \\
\mathrm{ng} / \mathrm{g}\end{array}$ \\
\hline Total Org Carbon & & & & & $0.88 \%$ & $0.87 \%$ & $1.41 \%$ & $0.2 \%$ & $0.64 \%$ & $1.15 \%$ & $0.83 \%$ & $0.75 \%$ & $0.32 \%$ & $0.55 \%$ \\
\hline Total PCBs & 22.7 & 180 & 120 & 6717 & 2119 & 931 & 1269 & 2745 & 6717 & 2097 & 1214 & 823 & 769 & 116 \\
\hline Naphthalene & 160 & 2100 & 990) & 201 & 91.0 & 92.9 & 47.6 & 201.1 & $150.9 \mathrm{~s}$ & 53.3 & $39.9 \mathrm{M}$ & 115.1 & 59.9 & $8.3 \mathrm{~J}$ \\
\hline C1-Naphthalenes & & & & 703 & 201.3 & 196.6 & 111.6 & 380.9 & $313.3 \mathrm{~s}$ & 138.1 & $91.6 \mathrm{M}$ & 703.5 & 444.7 & $14.5 \mathrm{~J}$ \\
\hline C2-Naphthalenes & & & & 12852 & 127.3 & 155.3 & 74.8 & 209.7 & $177.9 \$$ & 113.5 & $162.5 \mathrm{M}$ & 12852.1 & 383.2 & $13.1 \mathrm{~J}$ \\
\hline C3-Naphthalenes & & & & 1453 & 55.1 & 107.3 & 50.5 & 113.5 & $274.0 \$$ & 130.1 & 430.6 M & 1452.9 & 338.6 & $12.7 \mathrm{~J}$ \\
\hline C4-Naphthalenes & & & & 445 & 28.0 & 60.1 & 32.1 & $39.4 \mathrm{~J}$ & $272.9 \$$ & 110.2 & $275.5 \mathrm{M}$ & 444.7 & 170.6 & nd \\
\hline Biphenyl & & & & 61 & 22.2 & 34.7 & 22.4 & 60.8 & 31.1 \$ & 22.5 & $12.1 \mathrm{M}$ & 51.6 & $22.7 \mathrm{~J}$ & $3.0 \mathrm{~J}$ \\
\hline Acenaphthylene & 44 & 640 & 660 & & $3.8 \mathrm{~J}$ & $4.7 \mathrm{~J}$ & $2.6 \mathrm{~J}$ & $2.3 \mathrm{~J}$ & $4.5 \$ J$ & $2.9 \mathrm{~J}$ & $2.2 \mathrm{M}$ & $3.2 \mathrm{~J}$ & $1.8 \mathrm{~J}$ & $0.5 \mathrm{~J}$ \\
\hline Acenaphthene & 16 & 500 & 160 & 20 & $1.9 \mathrm{~J}$ & $6.0 \mathrm{~J}$ & $2.3 \mathrm{~J}$ & $7.5 \mathrm{~J}$ & $12.1 \$ J$ & $6.1 \mathrm{~J}$ & $3.8 \mathrm{M}$ & 20.3 & $7.7 \mathrm{~J}$ & $0.5 \mathrm{~J}$ \\
\hline Fluorene & 19 & 540 & 230 & 27 & $6.6 \mathrm{~J}$ & 13.1 & $5.8 \mathrm{~J}$ & $7.7 \mathrm{~J}$ & $14.0 \mathrm{~s}$ & 8.0 & $9.1 \mathrm{M}$ & 26.6 & $13.8 \mathrm{~J}$ & $0.9 \mathrm{~J}$ \\
\hline C1-Fluorenes & & & & 41 & $8.0 \mathrm{~J}$ & $16.2 \mathrm{~J}$ & $9.5 \mathrm{~J}$ & $13.2 \mathrm{~J}$ & 35.7 s & 20.2 & $24.0 \mathrm{M}$ & 40.6 & $17.0 \mathrm{~J}$ & nd \\
\hline C2-Fluorenes & & & & 111 & $12.2 \mathrm{~J}$ & 35.2 & 23.0 & $18.5 \mathrm{~J}$ & $110.5 \$$ & 52.7 & $74.4 \mathrm{M}$ & 80.9 & $30.0 \mathrm{~J}$ & nd \\
\hline C3-Fluorenes & & & & 152 & 21.5 & 57.1 & 36.3 & $46.0 \mathrm{~J}$ & $151.8 \mathrm{~s}$ & 63.5 & $94.6 \mathrm{M}$ & 101.6 & 41.2 & nd \\
\hline Phenanthrene & 240 & 1500 & 1,000 & 75 & 23.7 & 57.2 & 28.5 & $35.6 \mathrm{~J}$ & $\mathbf{5 3 . 0}$ & 29.5 & $37.8 \mathrm{M}$ & 75.1 & 49.3 & $3.0 \mathrm{~J}$ \\
\hline Anthracene & 85.3 & 1100 & 2,200 & 19 & $4.5 \mathrm{~J}$ & 13.1 & 6.5 & $16.4 \mathrm{~J}$ & 19.1 & 8.1 & $10.9 \mathrm{M}$ & 14.0 & $9.6 \mathrm{~J}$ & $0.6 \mathrm{~J}$ \\
\hline C1-Phenanthrene & & & & 261 & $15.6 \mathrm{~J}$ & 41.1 & 17.1 & $24.6 \mathrm{~J}$ & 61.6 & 260.5 & $40.7 \mathrm{M}$ & 78.8 & $21.1 \mathrm{~J}$ & $3.2 \mathrm{~J}$ \\
\hline C2-Phenanthrene & & & & 135 & $24.0 \mathrm{~J}$ & 76.4 & 37.2 & $41.5 \mathrm{~J}$ & 129.7 & 55.3 & $84.6 \mathrm{M}$ & 134.9 & $45.3 \mathrm{~J}$ & $6.0 \mathrm{~J}$ \\
\hline C3-Phenanthrene & & & & 263 & 49.3 & 118.8 & 73.2 & 116.5 & 263.4 & 111.6 & $130.2 \mathrm{M}$ & 141.4 & 60.6 & $6.8 \mathrm{~J}$ \\
\hline C4-Phenanthrene & & & & 109 & 37.5 & 98.9 & $\mathbf{5 5 . 0}$ & $65.6 \mathrm{~J}$ & 109.2 & 51.4 & $60.9 \mathrm{M}$ & 87.7 & $52.2 \mathrm{~J}$ & nd \\
\hline Dibenzothiophene & & & & 20 & $3.7 \mathrm{~J}$ & $8.2 \mathrm{~J}$ & $5.0 \mathrm{~J}$ & $11.5 \mathrm{~J}$ & 19.6 & $7.1 \mathrm{~J}$ & $12.0 \mathrm{M}$ & $15.5 \mathrm{~J}$ & $5.2 \mathrm{~J}$ & $0.5 \mathrm{~J}$ \\
\hline C1-Dibenzothiophene & & & & 49 & $6.3 \mathrm{~J}$ & $21.0 \mathrm{~J}$ & $12.7 \mathrm{~J}$ & $11.9 \mathrm{~J}$ & $35.0 \mathrm{~J}$ & $21.4 \mathrm{~J}$ & $25.9 \mathrm{M}$ & 49.5 & $11.3 \mathrm{~J}$ & $1.5 \mathrm{~J}$ \\
\hline C2-Dibenzothiophene & & & & 174 & $25.1 \mathrm{~J}$ & 89.4 & 46.7 & $37.5 \mathrm{~J}$ & 174.2 & 84.9 & $107.0 \mathrm{M}$ & 137.1 & $38.0 \mathrm{~J}$ & $4.8 \mathrm{~J}$ \\
\hline C3-Dibenzothiophene & & & & 257 & $27.0 \mathrm{~J}$ & 117.4 & 83.9 & $61.5 \mathrm{~J}$ & 257.4 & 113.0 & $146.9 \mathrm{M}$ & 131.2 & $51.5 \mathrm{~J}$ & $8.3 \mathrm{~J}$ \\
\hline Fluoranthene & 600 & 5100 & 1,600 & 84 & 18.8 & 73.9 & 49.4 & 39.2 & 84.3 & 39.8 & 45.1 M & 70.6 & 54.5 & $5.9 \mathrm{~J}$ \\
\hline Pyrene & 665 & 2600 & 10,000 & 95 & 23.6 & 65.5 & 41.5 & 40.7 & 95.0 & 44.9 & $52.8 \mathrm{M}$ & 74.4 & 68.9 & $5.8 \mathrm{~J}$ \\
\hline C1-Fluoranthene/Pyrene & & & & 84 & 16.7 & 43.4 & 31.4 & $36.6 \mathrm{~J}$ & 53.8 & 26.7 & $33.7 \mathrm{M}$ & 83.6 & 65.2 & $3.9 \mathrm{~J}$ \\
\hline Benz(a)anthracene & 261 & 1600 & 1,100 & 35 & 7.5 & 18.6 & 18.2 & 17.7 & 34.8 & 19.0 & $15.2 \mathrm{M}$ & 23.3 & 20.3 & $1.9 \mathrm{~J}$ \\
\hline Chrysene & 384 & 2800 & 1,100 & 29 & 17.4 & 21.7 & 26.7 & $35.0 \mathrm{~J}$ & 28.5 & 19.4 & 27.8 & 23.0 & $23.4 \mathrm{~J}$ & $3.7 \mathrm{~J}$ \\
\hline C1-Chrysenes & & & & 44 & $13.7 \mathrm{~J}$ & $21.9 \mathrm{~J}$ & 20.7 & $18.3 \mathrm{~J}$ & 43.8 & $15.7 \mathrm{~J}$ & $27.3 \mathrm{~J}$ & $24.8 \mathrm{~J}$ & $18.8 \mathrm{~J}$ & $5.9 \mathrm{~J}$ \\
\hline C2-Chrysenes & & & & 41 & $9.0 \mathrm{~J}$ & $20.1 \mathrm{~J}$ & $17.6 \mathrm{~J}$ & $22.1 \mathrm{~J}$ & 40.5 & $16.3 \mathrm{~J}$ & $21.6 \mathrm{~J}$ & $20.6 \mathrm{~J}$ & $14.6 \mathrm{~J}$ & $5.9 \mathrm{~J}$ \\
\hline C3-Chrysenes & & & & & $4.2 \mathrm{~J}$ & $6.4 \mathrm{~J}$ & $4.2 \mathrm{~J}$ & $4.5 \mathrm{~J}$ & $3.8 \mathrm{~J}$ & $2.0 \mathrm{~J}$ & $1.5 \mathrm{~J}$ & $5.1 \mathrm{~J}$ & $4.0 \mathrm{~J}$ & nd \\
\hline C4-Chrysenes & & & & & $8.2 \mathrm{~J}$ & nd & $2.1 \mathrm{~J}$ & $3.3 \mathrm{~J}$ & $4.0 \mathrm{~J}$ & $1.2 \mathrm{~J}$ & $1.5 \mathrm{~J}$ & $2.5 \mathrm{~J}$ & $4.4 \mathrm{~J}$ & nd \\
\hline Benzo(b)Auoranthene & & & & 11 & $7.3 \mathrm{~J}$ & $8.2 \mathrm{~J}$ & 11.0 & $13.0 \mathrm{~J}$ & $12.8 \mathrm{~J}$ & $9.3 \mathrm{~J}$ & $7.8 \mathrm{~J}$ & $10.9 \mathrm{~J}$ & $9.9 \mathrm{~J}$ & $2.3 \mathrm{~J}$ \\
\hline Benzo(k)Muoranthene & & & & 11 & $7.3 \mathrm{~J}$ & $7.7 \mathrm{~J}$ & 10.9 & $12.8 \mathrm{~J}$ & $12.7 \mathrm{~J}$ & $9.2 \mathrm{~J}$ & $7.8 \mathrm{~J}$ & $8.5 \mathrm{~J}$ & $9.8 \mathrm{~J}$ & $2.3 \mathrm{~J}$ \\
\hline Benzo(e)pyrene & & & & 14 & 8.8 & 9.2 & 10.1 & $14.3 \mathrm{~J}$ & 14.0 & 9.5 & 8.1 & 9.3 & $10.2 \mathrm{~J}$ & $3.5 \mathrm{~J}$ \\
\hline Benzo(a)pyrene & 430 & 1600 & 990 & 8 & $6.5 \mathrm{~J}$ & $7.1 \mathrm{~J}$ & 7.9 & $12.0 \mathrm{~J}$ & $11.4 \mathrm{~J}$ & $9.2 \mathrm{~J}$ & $7.4 \mathrm{~J}$ & $5.1 \mathrm{~J}$ & $5.9 \mathrm{~J}$ & $2.3 \mathrm{~J}$ \\
\hline Perylene & & & & & $2.3 \mathrm{~J}$ & $2.8 \mathrm{~J}$ & $3.0 \mathrm{~J}$ & $4.2 \mathrm{~J}$ & $6.3 \mathrm{~J}$ & $4.3 \mathrm{~J}$ & $3.4 \mathrm{~J}$ & $1.7 \mathrm{~J}$ & $2.7 \mathrm{~J}$ & $1.3 \mathrm{SJ}$ \\
\hline Indeno(1,2,3-cd)pyrene & & & 340 & 6 & $5.3 \mathrm{~J}$ & $4.0 \mathrm{~J}$ & 6.3 & $9.1 \mathrm{~J}$ & $6.9 \mathrm{~J}$ & 5.8 & $4.3 \mathrm{~J}$ & $3.4 \mathrm{~J}$ & $4.5 \mathrm{~J}$ & $1.7 \mathrm{~J}$ \\
\hline Dibenzo(ah)anthracene & 63.4 & 260 & 120 & & $1.6 \mathrm{~J}$ & $1.2 \mathrm{~J}$ & $2.0 \mathrm{~J}$ & $3.3 \mathrm{~J}$ & $2.1 \mathrm{~J}$ & $2.3 \mathrm{~J}$ & $1.7 \mathrm{~J}$ & $1.5 \mathrm{~J}$ & $2.0 \mathrm{~J}$ & $0.5 \mathrm{~J}$ \\
\hline Benz(ghi)perylene & & & 310 & 11 & 8.0 & 6.0 & 7.2 & $13.6 \mathrm{~J}$ & 10.9 & 7.3 & 6.3 & $5.2 \mathrm{~J}$ & $6.8 \mathrm{~J}$ & $4.6 \mathrm{~J}$ \\
\hline $\begin{array}{l}\text { Total PAHs } \\
\text { (w/o Perylene) }\end{array}$ & 4022 & 44792 & & 17130 & 959 & 1736 & 1052 & 1818 & 3130 & $1701 \mathrm{~J}$ & $2147 M$ & 17130 & 2198 & $138 \mathrm{~J}$ \\
\hline Low MoI Wt. PAHs & $\mathbf{5 5 2}$ & 3160 & 3700 & 16425 & 734 & 1184 & 636 & 1400 & 2185 & 1238 & 1586 & 16425 & 1769 & 73 \\
\hline High Mol Wt. PAHs & 1700 & 9600 & 9600 & 952 & 228 & 554 & 419 & 421 & 952 & 468 & 565 & 707 & 432 & 67 \\
\hline \multicolumn{15}{|l|}{ Specific PAHs } \\
\hline 2-Methylnaphthalene & 70 & 670 & 380 & 484 & 145.0 & 141.2 & 83.2 & 286.9 & $230.0 \$$ & 99.4 & $65.0 \mathrm{M}$ & 484.5 & 255.7 & $9.9 \mathrm{~J}$ \\
\hline 1-Methylnaphthalene & & & & 219 & 56.3 & 55.4 & 28.5 & 94.0 & $83.4 \$$ & 38.7 & $26.5 \mathrm{M}$ & 219.0 & 189.0 & 4.6 $\mathrm{J}$ \\
\hline 2,6-Dimethylnaphthalene & & & & 633 & 75.5 & 136.3 & 66.2 & 113.3 & $146.3 \$$ & 101.2 & $101.4 \mathrm{M}$ & 633.1 & 179.6 & $5.6 \mathrm{~J}$ \\
\hline 2,3,5-Trimethylnaphthalene & & & & 272 & 12.3 & 33.2 & 12.8 & $22.5 \mathrm{~J}$ & $72.3 \$$ & 36.5 & $77.2 \mathrm{M}$ & 271.8 & 75.3 & $0.9 \mathrm{~J}$ \\
\hline 1-Methylphenanthrene & & & & 21 & $3.5 \mathrm{~J}$ & $12.6 \mathrm{~J}$ & $5.4 \mathrm{~J}$ & $5.5 \mathrm{~J}$ & 20.5 & $7.6 \mathrm{~J}$ & $13.4 \mathrm{M}$ & 20.6 & $6.4 \mathrm{~J}$ & $0.5 \mathrm{~J}$ \\
\hline
\end{tabular}

$M=$ Interferences with secondary ion

$\$=$ Analyte quantified from secondary ion

$\mathbf{J}=$ Concentration below method detection limit

* = Washington State Marine Sediment Criteria Adjusted to 1\% organic carbon (WDOE 1991)

$+=$ Long et al. 1995 
and State of Washington marine sediment criteria, which are normalized to $1 \%$ carbon and the maximum level detected. Only L-125 exceeded any ERM for the PAHs.

A new screening procedure sensitive to PAH compounds was run on 32 of the bay samples and the control. Splits of all the sediment samples were sent to the EPA's Environmental Monitoring Systems Laboratory in Las Vegas where they were analyzed using a synchronous ultraviolet-visible fluorescence spectroscopy procedure (Amick 1994; Amick et al. 1995). To select a reference hydrocarbon for calibration of the instrument, a series of synchronous fluorescent scans were performed using a Perkin-Elmer LS50 on standard solutions containing known quantities of hydrocarbon-containing substances. These scans were compared with cyclohexane extracts of Winter Quarters Bay sediment samples. The hydrocarbon products evaluated included No. 2 diesel, No. 6 fuel oil, bunker C, various JP fuels, and lubricating oils. The best "fingerprint" match was with lubricating oil (Pennzoil SAE 30), which was then used for instrument calibration. The analytical results were expressed on a wet sediment basis and have been converted to dry weight as shown in Table 5 and Figure 8 (normalized to $1 \%$ carbon). The SAE 30 oil equivalent concentrations reported are much higher than the total PAH data reported by GERG (GERG looks for a specific suite of PAHs only). Reported levels ranged from 43 to $5,000 \mu \mathrm{g} / \mathrm{g}$ (ppm) for the bay samples with the control sample showing just $13 \mu \mathrm{g} / \mathrm{g}$. Interestingly, the GERG total PAH results do not correlate with the EPA results.

The prime purpose of mapping contamination in Winter Quarters Bay was to determine the geographic extent of toxicity based on analysis of both whole sediment samples, and solvent exchanged sample extracts. The cyclohexane extracts analyzed by the EPA were exchanged into dimethyl sulfoxide and analyzed for toxicity by Microbics Corporation, using a new, much more sensitive, chronic Microtox procedure. The new procedure is run for a 20- to 24-hour period, which covers several life cycles of the fluorescent bacterium Photobacterium phosphoreum. Chronic Microtox data appears to correlate very well with standard 14- and 28-day sediment toxicity tests using higher organisms. $\mathrm{f}$. The results of the tests are presented in Table 5. EC 50 data were generated by Thomas Johnson, Midwest Science Center who analyzed sediment extracts using the standard Microtox procedure and the lowest-observed-effect-level (LOEC) data were generated by Microbics Corporation on both whole sediments and sediment extracts using the Microtox chronic test. Samples with the highest toxicity have the lowest numerical value.

Results show high levels of toxicity in both solvent extracts of sediments and whole sediment samples (Figure 9). During analysis of these data, a correlation matrix was run comparing chronic Microtox toxicity in whole and solvent extracts of sediment with contaminant concentrations expressed on wet and dry weights as well as normalized to organic carbon. Because of apparent outliers in the data, Spearman Correlation Coefficients (nonparametric test) were calculated. The results indicated the following:

- Solvent extract toxicity was significantly correlated ( $95 \%$ probability level) with the following:

- Oil-equivalent (wet, dry and $1 \%$ organic carbon), Johnson and Microbics data

- $\quad$ PAHs (wet, dry), Johnson data

f. Personal communication with Christopher Ingersoll, Midwest Science Center. 


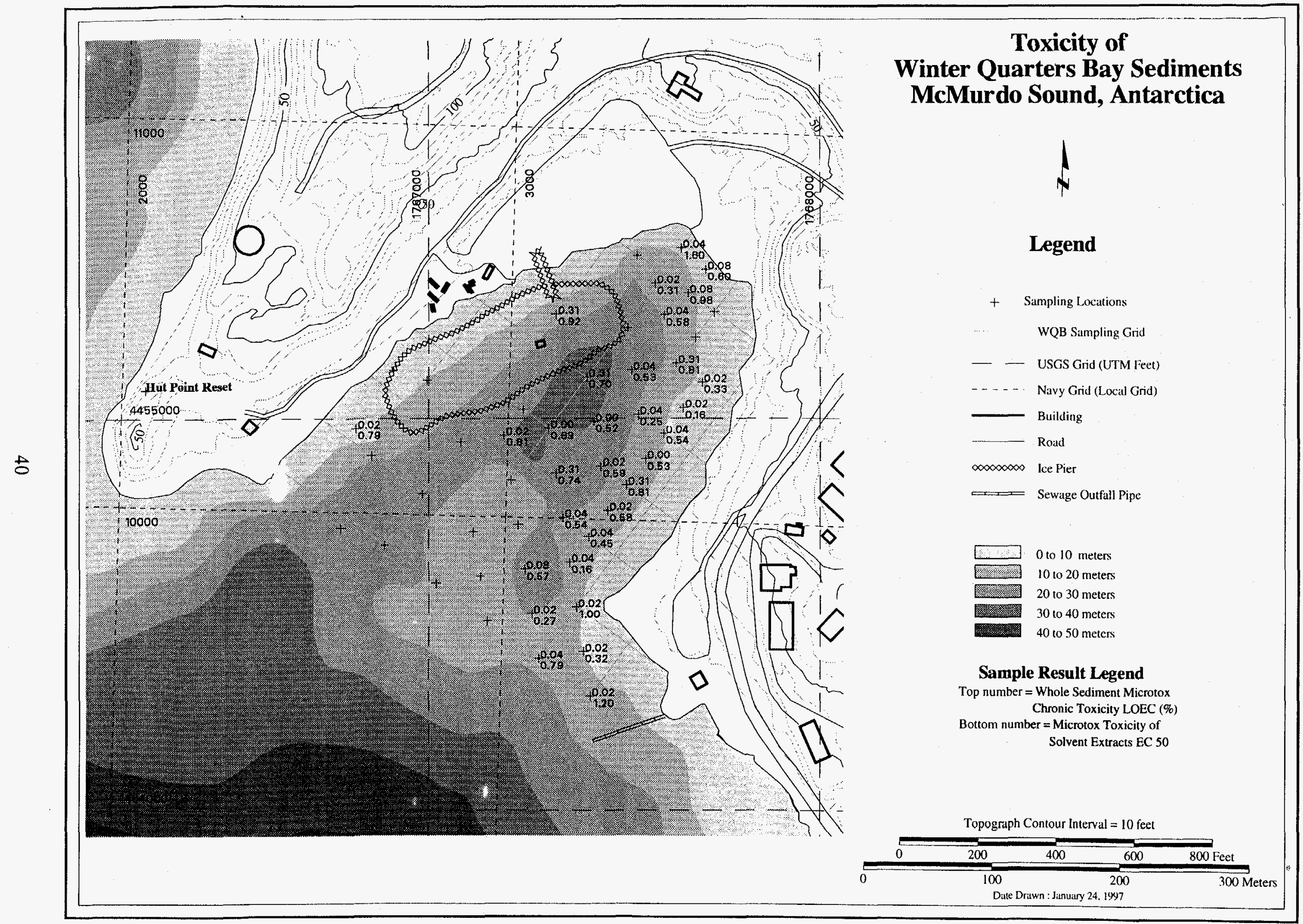

Figure 9. Toxicity of Winter Quarters Bay sediments, McMurdo Sound, Antarctica. 
- TOC (Johnson data only)

- Moisture, Microbics data only

- $\quad$ Silt, Johnson and Microbics data

- Clay, Johnson and Microbics data

- Whole sediment toxicity significantly correlated with the following:

- Oil-equivalent (dry weight basis)

- Moisture

- Silt

- Clay.

Further testing showed whole sediment toxicity was significantly correlated with log transformed PCBs using the Pearson correlation coefficient and deleting one outlier. In general, normalization to $1 \%$ organic carbon did not improve correlations as might be expected.

All chemical characterization of Winters Quarters Bay contamination has been directed at sediments and biota. Because no water quality sampling for other than for coliform bacteria has been conducted, arrangements were made by the INEEL to have a water sample collected from what was expected to be potentially the most contaminated water in the bay. Conductivity, temperature, and depth (CTD) measurements had revealed a brine pool below about $23 \mathrm{~m}$ in the bay in areas in which conditions of higher elevated salinity, decreased temperature, decreased oxygen, and decreased pH existed in December 1993. These data indicate a stagnant water body in which contaminants being evolved from contaminated sediments would be highest because of poor mixing. A water sample was collected with a polytetrafluoroethylene Kemmerer water sampler on December 17, 1994, at a depth of about $30 \mathrm{~m}$ and was analyzed for VOCs and semivolatile organic compounds by GP Environmental Service using EPA methods. The sample for volatile analytes was analyzed on January 16,1995, and it had been acidified which extends the holding time to 30 days. The only compounds detected were 1,2 dichloroethane at $1.2 \mu \mathrm{g} / \mathrm{L}$, methylene chloride at $3.9 \mu \mathrm{g} / \mathrm{L}$ (blank had $2.6 \mu \mathrm{g} / \mathrm{L}$ of methylene chloride) and toluene at $1.1 \mu \mathrm{g} / \mathrm{L}$. The sample analyzed for semivolatile organics was extracted on January 13,1995, well beyond the 7-day holding time, and no target compound was detected above the detection limits of 10 to $50 \mu \mathrm{g} / \mathrm{L}$. While the latter results may be low due to sample degradation and the long holding time, the VOC data should be valid.

As another measure of water quality, lipid dosimeters (Lebo et al. 1992) were deployed by the INEEL about $3 \mathrm{~m}$ above the bottom of the deep stagnant area of the bay (location I-175). The dosimeters remained in place and were retrieved by ASA personnel and analyzed at the Midwest Science Center. No PCBs above background were detected and total PAHs also were below the detection limit. Dosimeters also have been 
deployed in Winter Quarters Bay sediments, and a final report was written though it has not been released by NSF. The limited data on contaminants in bay water show only low levels of contamination.

Because of the small amount of rigorous PCB and PAH data (9 samples), the scatter of the results, and differences between various statistical procedures, it is difficult to draw any strong conclusions about which contaminant(s) may be causing the observed benthic impacts. Investigators recommended the analysis more of the INEEL collected samples (archived at GERG) for PCBs and PAHs to increase the size of the database and to better determine associations between contaminants and sediment toxicity.

Overall, the results of comparing Winters Quarters Bay contaminant levels in sediment versus marine sediment quality criteria developed by Long et al. (1995) imply that PCBs are the most suspect contaminant because PCB levels most consistently exceed ERM levels. The toxicity data on whole sediments implicates "oil equivalent" data as determined by the EPA. However, no attempt has yet been made to assess possible metal toxicity using acid volatile sulfides and simultaneously extracted metal ratios. In addition, no laboratory studies have been conducted using higher level organisms to relate toxicity to available levels of contaminants. Unionized ammonia has often been associated with sediment toxicity, and no attempt has been made to measure those levels either. The source of the toxic impacts to bay sediments remains unknown. One more possibility is that the contaminants that have caused the toxic impacts have largely degraded but recovery is impeded by the residual contamination and cold temperature. 


\section{SUMMARY AND RECOMMENDATIONS}

Considerable information has been generated during the past 30 years about the potential contamination of Winter Quarters Bay and the impacts to ecological systems from this contamination. This information comes from both sponsored research and environmental support contractors. Collectively, these studies indicate elevated levels of several contaminants in the sediments of the bay. These contaminants include metals, PCBs, and a variety of fuel-related compounds. The studies conducted to date also suggest that adverse ecological effects have occurred from one or more of the contaminants found in the bay. Information on past waste disposal practices and observations of large quantities of trash present on the bottom surface of the bay provide further evidence that the bay has been adversely impacted by human activities.

The original intent of this report was to provide background information for participants in an NSF-sponsored workshop on the condition of Winter Quarters Bay. Participants of the workshop were to include experts with knowledge of the bay and the surrounding areas, remediation experts from the EPA and the U.S. Army Corps of Engineers, scientists from NOAA, etc. The goal of the workshop was, therefore, to assist the NSF in making decisions regarding the remediation of the bay.

While significant data exists, much is still unknown about the bay. Fundamental information needs include a vertical profile of contamination within the sediments, sediment deposition rates, potential sources of contaminants, the rates at which contaminants migrate into the bay from the various sources, the rates at which contaminants migrate out of the bay by various pathways, and the specific contaminants that are responsible for the apparent toxic effects.

An integrated research plan should be developed that is focused on determining what additional information, if any, is needed to make informed decisions on the remediation of Winter Quarters Bay. Ultimately, decisions must be made about the need for remediation and the best methods for conducting any remediation. While many conventional remediation techniques likely would be extremely difficult to implement in Antarctica, some practices such as in situ capping might prove feasible.

Finally, the authors strongly recommend that the NSF sponsor a workshop for the purpose of determining what, if anything, should be done to remediate the impacts from chemical contaminants in Winter Quarters Bay. The policy of the NSF is to comply with the spirit of U.S. environmental regulations while providing equivalent or superior environmental protection to the extent practicable. In recent years, much progress has been accomplished in this direction in and around McMurdo Station. The authors suggest that the next challenge is to address marine contamination of Winter Quarters Bay. 


\section{REFERENCES}

AECOM, 1992, Final Fortress Rocks Landfill Remediation Report for McMurdo Station, Antarctica, Fairfax, Virginia, 1992.

Amick, E. M., 1994, Analysis of Sediment Samples from Winter Quarters Bay at McMurdo Station in Antarctica by Synchronous Ultraviolet-Visible Fluorescence Spectroscopy, Lockheed Environmental Systems and Technologies Company for Environmental Monitoring Systems Laboratory, U.S. Environmental Protection Agency, Las Vegas, Nevada, 1994.

Amick, E. N., J. E. Pollard, W. H. Engelmann, K. W. Brown, J. P. Alarie, W. Watts, T. Vo-Dinh, Akindele, F. M., and Crockett, A. B., 1995, "Polycyclic Aromatic Hydrocarbons from U.S. and Antarctic Sites Analyzed with Synchronous Fluorescence Spectrometry," in Proceeding, Fourth International Symposium on Field Screening Methods for Hazardous Wastes and Toxic Chemicals, Air and Waste Management Association, 1995.

ANL, 1992, Preliminary Site Investigation at McMurdo Station, Ross Island, Antarctica, Argonne National Laboratory, July 1992.

Arntz., W. E., and V. A. Gallardo, 1993, "Antarctic Benthos: Present Position and Future Prospects," Proceedings: SCAR Antarctic Science, Global Concerns Conference, Bremen, Springer, Berlin, September 1991.

Aschan, M. M., and A. M. Skullerud, 1990, "Effects of Changes in Sewage Pollution on Soft-BottomMacrofauna Communities in the Inner Oslofjord, Norway," Sarsia, 75, 1990, pp. 169-190.

Barry, J. P., and P. K. Dayton, 1988, "Current Patterns in McMurdo Sound, Antarctica, and Their Implications for Productivity of Local Benthic Communities, Polar Biology, 8, 1988, pp. 367-376.

Barry, J. P., 1988, "Hydrographic Patterns in McMurdo Sound, Antarctica, and Their Relationship to Local Benthic Communities," Polar Biology, 8, 1988, pp. 377-391.

Barry, J. P., 1994, Ocean Current Observations near McMurdo Station, Antarctica for 1991 to 1993 : Relation to Wastewater Discharge Dispersal, EGG-CIET-11280, EG\&G Idaho, Inc., Idaho Falls, Idaho, 1994, $91 \mathrm{pp}$.

Barry, J. P., 1995, Ocean Current Observations near McMurdo Station, Antarctica, 1993 to 1994: Relation to Wastewater Discharge Dispersal, INEL-95/0362, Lockheed Martin Idaho Technologies Company, Idaho Falls, Idaho, 1995, 106 pp.

Boesch, D. F., 1982, "Ecosystem Consequences of Alterations of Benthic Community Structure and Function in the New York Bight," in Ecological Stress and the New York Bight: Science and Management, G. F. Mayer, ed., Esturaine Research Federation, Columbia, South Carolina, 1982, pp. 543-568. 
Cameron, R. E., 1972, "Pollution and Conservation of the Antarctic Terrestrial Ecosystem," in Proceedings of the Colloquium on Conservation Problems in Antarctica, B.C. Parker, ed., Allen Press, 1972, pp. 267-306.

Consoer Townsend, 1995, Sampling and Analysis Report - Winter Quarters Bay Landfill, McMurdo Station, Antarctica, Vol. I, Consoer Townsend and Associates, Fairfax, Virginia, April 1995.

Crockett, A. B., 1994, FY-1993 Environmental Sampling and Analysis Report for Wastewater Discharge at McMurdo Station, Antarctica, EGG-CIET-11127, EG\&G Idaho, Inc., Idaho Falls, Idaho, 1994, 65 pp.

Crockett, A. B., 1997, "Background Levels of Metals in Soils, McMurdo Station, Antarctica,"Environmental Monitoring and Assessment, in press.

Crockett, A. B., 1997, "Water and Wastewater Quality Monitoring, McMurdo Station, Antarctica," Environmental Monitoring and Assessment, in press.

Cross, W. E., and D. H. Thompson, 1987, "Effects of Experimental Releases of Oil and Dispersed Oil Arctic Nearshore Macrobenthos," Vol. 1, "Infauna," Arctic, 40 (supplement 1), 1987, pp. 184-200.

Davis, P. H., and R. B. Spies, 1980, "Infaunal Benthos of a Natural Petroleum Seep: Study of Community Structure," Marine Biology, 59, 1980, pp. 31-41.

Davies, J. M., J. M. Addey, R. A. Blackman, J. R. Blanchards, J. E. Ferbrache, D. C. Moore, H. J. Somerville, A. Whitehead, and T. Wilkinson, 1984, "Environmental Effects of the Use of Oil-Based Drilling Muds in the North Sea,"Marine Pollution Bulletin, 15, 1984, pp. 363-370.

Dayton, P. K., G. A. Robilliard, and A. L. DeVries, 1969, “Anchor Ice Formation in McMurdo Sound, Antarctic, and Its Biological Effects," Science, 163, 1969, pp. 273-274.

Dayton, P. K., G. A. Robilliard, and R. T. Paine, 1970, "Benthic Faunal Zonation as a Result of Anchor Ice at McMurdo Sound, Antarctica," Antarctic Ecology, M. W. Holdgate, ed., Academic Press, New York, Vol. 1, 1970, pp. 244-258.

Dayton, P. K., and R. T. Robilliard, 1971, "Implications of Pollution to the McMurdo Sound Benthos," Antarctic Journal, 6, 1971, pp. 53-56.

Dayton, P. K., 1972, "Toward an Understanding of Community Resilience and the Potential Effects of Enrichment to the Benthos at McMurdo Sound, Antarctica, Proceedings of the Colloquium on Conservation Problems in Antarctica, B.C. Parker, ed., Allen Press, pp. 81-95.

Dayton, P. K., G. A. Robilliard, R. T. Paine, and L. B. Dayton, 1974, "Biological Accommodation in the Benthic Community at McMurdo Sound, Antarctica," Ecological Monographs, 44, 1974, pp. $105-128$.

Dayton, P. K., and J. S. Oliver, 1977, "Antarctic Soft-Bottom Benthos in Oligotrophic and Eutrophic Environments," Science, 197, pp. 55-58. 
Dayton, P. K., 1989, "Interdecadal Variation in an Antarctic Sponge and Its Predators from Oceanographic Climate Shifts," Science, 245, 1989, pp. 1484-1486.

Dayton, P. K, 1990, "Polar Benthos," Polar Oceanography, Part B: Chemistry, Biology and Geology, Academic Press, New York, Chapter 12, 1990.

Dayton, P. K., B. J. Mordida, and F. Bacon, 1994, "Polar Marine Communities," American Zoologist, 34, 1994, pp. 90-99.

Dearborn, J H, 1965, "Ecological and Faunistic Investigations of the Marine Benthos at McMurdo Sound, Antarctica," Doctoral Dissertation, Stanford University, Stanford, California, 1965.

Delille, D., and N. Vaillant, 1990, "The Influence of Crude Oil on the Growth of Subantarctic Marine Bacteria," Antarctic Science, 2, 1990, pp. 123-127.

Dell, R. K. 1972, “Antarctic Benthos," Advances in Marine Biology, 10, 1972, pp. 1-216.

Denton, G. H., R. L. Armstrong, and M. Stuvier, 1971, Late Cenozoic Glacial Ice Ages, K. K. Turkian, ed., Yale University Press, New Haven, Connecticut, 1971, pp. 267-306.

Ellis, D. V., and R. T. Wilce, 1961, "Arctic and Subarctic Examples of Intertidal Zonation," Arctic, 14, 1961, pp. 224-235.

Fleeger, J. W., and G. T. Chandler, 1983, "Meiofauna Responses to an Experimental Oil Spill in a Louisiana Salt Marsh," Marine Ecology Progress Series, 118, 1983, pp. 49-58.

Foster, M. S., A. P. DeVogelaere, C. Harrold, J. S. Pearse, and A. B. Thum, 1988, "Causes of Spatial and Temporal Patterns in Rocky Intertidal Communities of Central and Northern California,"Memoirs of the California Academy of Sciences, Number 9, 1988, 45 pp.

Grassle, J. F., and J. P. Grassle, 1974, "Opportunistic Life Histories and Genetic Systems in Marine Benthic Polychaetes," Journal of Marine Research, 32, 1974, pp. 253-284.

Grassle, J. F., and J. P. Grassle, 1976, "Sibling Species in the Marine Pollution Indicator Capitella (Polychaeta),"Science, 192, 1976, pp. 567-569.

Gray, J. S., K. R. Clarke, R. M. Warwick, and G. Hobbs, 1990, "Detection of Initial Pollution on Marine Benthos: An Example from the Ekofisk and Eldfisk Oilfields, North Sea," Marine Ecology Progress Series, 66, 1990, pp. 285-299.

Grebmeier, J. M., and J. P. Barry, 1991, "The Influence of Oceanographic Processes on Pelagic-Benthic Coupling in Polar Regions: A Benthic Perspective," Journal of Marine Systematics, 2, 1991 , pp. 498-518. 
Heine, J. M., 1989, "Effects of Ice Scour on the Structure of Sublittoral Marine Algal Assemblages of St.

Lawerence and St. Matthew Islands, Alaska," Marine Ecology Progress Series, 52, 1989, pp. 253-260.

Kennicutt, M., S. J. McDonald, J. L. Sericano, P. Boothe, J. Oliver, S. Safe, B. J. Presley, H. Liu, D. Wolfe, T. Wade, A. Crockett, D. Bockus, 1995, "Human Contamination of the Marine Environment-Arthur Harbor and McMurdo Sound, Antarctica," Environmental Science and Technology, 29, 1995, pp. 1279-1287.

Knox, G. A., and J. K. Lowry, 1977, "A Comparison Between the Benthos of the Southern Ocean and the North Polar Ocean with Special Reference to the Amphipoda and the Polychaetes," Polar Oceans, M.J. Dunbar, ed., Arctic Institute of North America, Calgary, Alberta, 1977, pp. 423-462.

Lebo, J. A., J. L. Zajicek, J. N. Huckins, J. D. Petty, P. H. Peterman, and R. W. Gale, 1992, "Use of Semipermeable Membrane Devices for in Situ Monitoring of Polycyclic Aromatic Hydrocarbons in Aquatic Environments," Chemosphere, 25, 1992, pp. 697-718.

Leahy and Colwell, 1990, "Microbial Degradation of Hydrocarbons in the Environment," Microbiological Review, 54, 1990, pp. 305-315.

Lenihan, H. S., J. S. Oliver, J. M. Oakden, and M. A. Stephenson, 1990, "Intense and Localized Benthic Marine Pollution Around McMurdo Station, Antarctica,"Marine Pollution Bulletin, 21, 1990, pp. $422-430$.

Lenihan, H. S., and J. S. Oliver, 1995, "Anthropogenic and Natural Disturbances to Marine Benthic Communities in Antarctica," Ecological Applications, 5, 1995, 311-326.

Lenihan, H. S., K. A. Kiest, K. E. Conlan, P. N. Slattery, B. H. Konar, and J. S. Oliver, 1995, "Patterns of Survival and Behavior in Antarctic Benthic Invertebrates Exposed to Contaminated Sediments: Field and Laboratory Bioassay Experiments," J. of Marine Biology and Ecology, 192, 1995, 233-255.

Littlepage, J. L. and J. S. Pearse, 1962, "Biological and Oceanographic Observations under an Antarctic Ice Shelf," Science, 137, pp. 679-680.

Long, E. R., D. D. MacDonald, S. L. Smith and F. D. Calder, 1995, "Incidence of Adverse Biological Effects within Ranges of Chemical Concentrations in Marine and Estuarine Sediments," Environmental Management, 19, 1995, pp. 81-97.

MLML, 1994, Biological Impacts of McMurdo Anthropogenic Disturbances to Marine Benthic near McMurdo Station, Antarctica: Benthic Monitoring Program 1988-1993 Data Report, Moss Landing Marine Laboratories, Moss Landing, California, 1994.

NOAA, 1993, Sampling and Analytical Methods of the National Status and Trends Program National Benthic Surveillance and Mussel Watch Projects 1984-1992, Volume IV, Comprehensive Descriptions of Trace Organic Analytical Methods, NOS ORCA 71, National Oceanic and Atmospheric Administration, 1993, 181 pp. 
NSF, 1989, Environmental Impact Assessment for Improvement of Sanitary Wastewater Management at McMurdo Station, Antarctica, National Science Foundation, Division of Polar Programs, Washington D.C., December 1, 1989.

NSF, 1991, Supplemental Environmental Impact Statement for the United States Antarctic Program, National Science Foundation, Division of Polar Programs, Washington D.C., October, 1991.

NSFA, 1981, Report of Operation Deep Freeze 81, 1980-1991, U.S. Navy, Naval Support Force Antarctica, COMNAVSUPPFORANTARCTICA, Port Hueneme, California, 1981.

NSFA, 1990, Report on Operation Deep Freeze 1989-1990, U.S. Navy, Naval Support Force Antarctica, COMNAVSUPPFORANTARCTICA, Port Hueneme, California, 1990.

Oliver, J. S., 1984, "Selection for Asexual Reproduction in an Antarctic Polychaete Worm," Marine Ecology Progress Series, 19, 1984, pp. 33-38.

Oliver, J. S., and P. N. Slattery, 1985, "Effects of Crustacean Predators on Species Composition and Population Structure of Soft-Bodied Infauna from McMurdo Sound, Antarctica," Ophelia, 24, 1985, pp. 155-175.

Picken, G. B., 1985, "Benthic Research in Antarctica: Past, Present and Future," Marine Biology of Polar Regions and Effects of Stress on Marine Organisms, J. S. Gray and M. E. Christiansen, eds., Wiley, Chicherster, 1985, pp. 167-183.

Raytheon, 1983, Report on the McMurdo Station Water Quality Study, Raytheon Services Company, Middletown, Rhode Island, Performed for ITT Antarctic Services, Paramus, New Jersey, 1983.

Risebrough, R. W., B. W. De Lappe, and C. Younghans-Haug, 1990, "PCB and PCTS Contamination in Winter Quarters Bay, Antarctica," Marine Pollution Bulletin, 21, 1990, pp. 523-529.

Robilliard, G. A., and M. Busdosh, 1981, "Need for Real World Assessment of the Environmenial Effects of Oil Spills in Ice-Infested Marine Environments," Proceedings of the Sixth International Conference on Port and Ocean Engineering under Arctic Conditions, Quebec, Canada, July 27-31, 1981, pp. 937-944.

Sanders, H. L., J. F. Grassle, G. T. Hampson, L. S. Morse, S. Garner-Price, and C. C. Jones, 1980, “Anatomy of an Oil Spill: Long-Term Effects from the Grounding of the Barge Florida off West Falmouth, Massachusetts," Journal of Marine Research, 38, 1980, pp. 265-380.

Scherrer, P., and J. Mille, 1989, "Biodegradation of Crude Oil in an Experimentally Polluted Peaty Mangrove Soil," Marine Pollution Bulletin, 20, 1989, pp. 430-432.

Spies, R. B., D. D. Hardin, and J. P. Toal, 1988, "Organic Enrichment or Toxicity? A Comparison of the Effects of Kelp and Crude Oil in Sediments on the Colonization and Growth of Benthic Infauna," Journal of Experimental Marine Biology and Ecology, 124, 1988, pp. 261-282. 
Swartz, R. C., F. A. Cole, D. W. Shults, and W. A. Deven, 1986, "Ecological Changes in the Southern California Bight near a Large Sewage Outfall; Benthic Conditions 1980-1983," Marine Ecology Progress Series, 31, 1986, pp. 1-13.

WDOE, 1991, Sediment Management Standards, Chapter-204, WAC, Washington State Department of Ecology. Olympia, Washington, 1991.

White, M. G., 1984, "Marine Benthos," Antarctic Ecology, Vol. 2, R.M. Laws, ed., Academic Press, London., pp. 421-462. 
Appendix A

\section{Coordinates and Depths of Winter Quarters Bay Sampling Sites}



Table A-1. Coordinates and depths of Winter Quarters Bay sampling sites.

\begin{tabular}{|c|c|c|c|}
\hline Site & Northing $(\mathrm{ft})$ & Easting (ft) & Depth (m) \\
\hline$A-25$ & 9548.4 & 3218.5 & 13.4 \\
\hline A-75 & 9641.7 & 3083.5 & 18.7 \\
\hline A-125 & 9734.8 & 2948.5 & 16.6 \\
\hline A-175 & 9828.0 & 2813.5 & 19.8 \\
\hline A- 225 & 9921.2 & 2678.5 & 23.4 \\
\hline A-261 & 9961.3 & 2562.7 & 27.2 \\
\hline B-50 & 9662.6 & 3197.6 & 10.3 \\
\hline B-100 & 9755.7 & 3062.6 & 20.6 \\
\hline B- 150 & 9848.9 & 2927.6 & 15.2 \\
\hline C-75 & 9776.7 & 3176.7 & 12.8 \\
\hline C- 125 & 9869.8 & 3041.7 & 21.5 \\
\hline$C-175$ & 9963.0 & 2906.7 & 13.9 \\
\hline C- 225 & 10056.2 & 2771.7 & 23.3 \\
\hline C- 275 & 10149.4 & 2636.7 & 18.4 \\
\hline C-298 & 101216.6 & 2591.4 & 16.5 \\
\hline D-100 & 9890.7 & 3155.8 & 18.4 \\
\hline D-150 & 9983.9 & 3020.8 & 19.0 \\
\hline E-100 & 9958.2 & 3202.4 & 14.0 \\
\hline E-125 & 10004.8 & 3134.9 & 20.4 \\
\hline E-175 & 10098.0 & 2999.9 & 17.2 \\
\hline E-225 & 10191.2 & 2864.9 & 23.2 \\
\hline F-100 & 10025.7 & 3249.0 & 15.5 \\
\hline F-150 & 10118.9 & 3114.0 & 23.4 \\
\hline F-200 & 10212.1 & 2979.0 & 28.9 \\
\hline G-100 & 10093.2 & 3295.6 & 15.0 \\
\hline G-125 & 10139.8 & 3228.1 & 22.8 \\
\hline G-175 & 10233.0 & 3093.1 & 30.6 \\
\hline G-200 & 10279.6 & 3025.6 & 29.6 \\
\hline $\mathrm{H}-100$ & 10160.8 & 3342.2 & 14.2 \\
\hline H- 150 & 10253.9 & 3207.2 & 30.5 \\
\hline I-100 & 10228.3 & 3388.8 & 10.5 \\
\hline I- 125 & 10274.9 & 3321.3 & 19.5 \\
\hline I-175 & 10368.0 & 3186.3 & 33.7 \\
\hline$J-100$ & 10295.7 & 3435.4 & 7.4 \\
\hline$J-150$ & 10389.0 & 3300.4 & 25.4 \\
\hline $\mathrm{K}-100$ & 10363.2 & 3482.0 & 8.1 \\
\hline K-125 & 10409.8 & 3414.5 & 17.0 \\
\hline $\mathrm{K}-172$ & 10497.4 & 3287.6 & 26.3 \\
\hline L-125 & 10477.3 & 3461.1 & 10.4 \\
\hline L-155 & 10533.2 & 3380.1 & 19.6 \\
\hline M-125 & 10544.8 & 3507.7 & 6.9 \\
\hline M-150 & 10591.4 & 3440.2 & 12.9 \\
\hline M-175 & 10613.7 & 3353.9 & 17.6 \\
\hline M-200 & 10684.6 & 3305.2 & 13.0 \\
\hline $\mathrm{N}-150$ & 10653.5 & 3483.0 & 5.4 \\
\hline N-175 & 10705.5 & 3419.0 & 8.2 \\
\hline
\end{tabular}

Coordinates based on McMurdo Station's Local Grid

Depth as measured, not adjusted for tides 